\title{
Are U-Th dates correlated with historical records of earthquakes? Constraints from co-seismic carbonate veins within the North Anatolian Fault Zone
}

\author{
Volkan Karabacak $^{1,2}$, I. Tonguç Uysal ${ }^{3}$, Halim Mutlu ${ }^{4}$, Ezgi Ünal-İmer ${ }^{5}$, R. Kadir Dirik ${ }^{6}$, \\ Yue-xing Feng ${ }^{7}$, Sinan Akıska ${ }^{4}$, İsmail Aydoğdu ${ }^{6}$, Jian-xin Zhao $^{7}$
}

1. Department of Geological Engineering, Eskisehir Osmangazi University, Eskisehir, Turkey

2. School of Earth Sciences, The University of Melbourne, Melbourne, VIC 3010, Australia

3. The Commonwealth Scientific and Industrial Research Organization (CSIRO) Energy, Perth, WA 6151, Australia

4. Department of Geological Engineering, Ankara University, Ankara, Turkey

5. Department of Geological Engineering, Middle East Technical University, Ankara, Turkey

6. Department of Geological Engineering, Hacettepe University, Ankara, Turkey

7. Radiogenic Isotope Facility, School of Earth and Environmental Sciences, The University of Queensland, Brisbane, QLD 4072, Australia

Corresponding author: Volkan Karabacak (karabacak1977@gmail.com)

\section{Key Points:}

- Age distributions of co-seismic carbonate veins are comparable with historical earthquakes.

This is the author manuscript accepted for publication and has undergone full peer review but has not been through the copyediting, typesetting, pagination and proofreading process, which may lead to differences between this version and the Version of Record. Please cite this article as doi: 10.1029/2018TC005450

This article is protected by copyright. All rights reserved. 
- Co-seismic carbonates are precipitated with the close-epicentre $(\mathrm{d}<200 \mathrm{~km})$ and highintensity (I>VI) earthquakes.

- Co-seismic carbonates are a good candidate to determine the long-term seismic release records. 


\begin{abstract}
U-Th dating of carbonate veins in connection with active tectonics has recently been used as an attractive tool for constraining the absolute timing of late Quaternary crustal deformations. In this study, for the first time we correlate U-Th ages of travertine deposits in co-seismic fissures along the North Anatolian Fault Zone (NAFZ) with records of paleoseismological studies supported by historical earthquake catalogued data. U-Th ages are assessed in relation to the recurrence interval and the size and epicentre distance of major Holocene earthquakes. Our statistical evaluations on age correlations indicate that the carbonate vein precipitation is concentrated in eight different periods along the NAFZ. The periods are well correlated with historical earthquake records and with previous dating results of the nearby trench studies. At least six of the periods correspond to the earthquakes reported in the historical catalogues. The age correlations of carbonate precipitation intervals for the last millennium show a recurrence along the eastern NAFZ with a mode at 130-330 years that is consistent with a previously proposed paleoseismic recurrence interval of the fault. Recorded events in carbonate veins indicate a close-epicentre $(\mathrm{d}<200 \mathrm{~km})$ and high-intensity $(\mathrm{I}>\mathrm{VI})$ paleoearthquakes. Our results suggest that co-seismic carbonate veins could be used to determine paleoseismic records as a supplementary tool to augment paleoseismological techniques. This tool has advantages over traditional paleoseismological methods for the understanding of long-term earthquake behaviour, particularly for prehistoric late Pleistocene events which cannot be dated easily by traditional paleoseismological methods.
\end{abstract}

\title{
1 Introduction
}

$\mathrm{CO}_{2}$-rich spring waters under high pressure in subsurface reservoirs are mobilized during sudden crustal strain (Montgomery and Manga 2003, Wang et al. 2004, Berardi et al. 2016, Karabacak et al. 2017) giving rise to carbonate precipitation within fractures that act as a conduit for hot waters (Sibson 1987, Altunel and Karabacak 2005) (Figure 1a). Such carbonate precipitation is therefore associated with co-seismic activities of faults, owing to the rapid precipitation from surface water enriched in $\mathrm{CO}_{2}$ of deep origin (Uysal et al. 2007, 2011, Brogi and Capezzuoli 2014). Moreover, precipitation of banded carbonate veins has been considered to be a result of repeated seismic releases (e.g., Altunel and Karabacak 2005, Uysal et al. 2007, Mesci et al. 2008, Nuriel et al. 2012, Brogi et al. 2017, Williams et al. 2017) (Figure 1b). However, independent earthquake chronologies were not available to test correlations with vein U-Th ages in previous studies. Thus, it is imperative to test this method in areas with dense seismic records and further assess the relationship between carbonate precipitation and fault activity. 
Along the segments of the North Anatolian Fault Zone (NAFZ), hot springs and related carbonate veins occur within well-developed fracture systems (Figure 2a). The NAFZ is also one of the most popular active plate boundaries for paleoseismological studies with the support of the earthquake catalogues extending back thousands of years. This fault zone has produced a sequence of catastrophic earthquakes during the 20th century (Figure 2a), commencing in the east with the 1939 Erzincan earthquake and progressing westward with an increase in the stress on nearby segments (Stein et al. 1997, Şengör et al. 2005). As such, tremendous efforts have been made to assess the seismic behaviour of the NAFZ based on historical and prehistorical seismic records (e.g., Barka 1996, Hubert-Ferrari et al. 2000, Rockwell et al. 2009). For example, across the segment of the 1939 Erzincan earthquake-rupture, most studies were carried out through paleoseismic trenching of Holocene fluvial and alluvial deposits for the identification of paleo earthquakes (e.g., Hartleb et al. 2006, Fraser 2009, Kozac1 et al. 2011, Zabc1 et al. 2011, Fraser et al. 2012, Polat et al. 2012) (Figure 2b). Therefore, the correlation of the timing of carbonate precipitation with paleoseismic records in this region may provide significant supplementary chronological data.

Paleoseismological studies are mainly based on the interpretation of data of depositional and erosional processes spanning from the Holocene to the present day. Different approaches and techniques (e.g. ${ }^{14} \mathrm{C}$, TL/OSL) are used for dating samples showing direct or indirect evidence of paleo earthquake activity (e.g. McCalpin 2009, Bronk-Ramsey 2014, Gray et al. 2015). Most studies deal with stratigraphic ordering constraints and date the pre-seismic or post-seismic geological units to estimate the event horizon of the earthquake (Allen 1986, McCalpin 2009). All models assume that the samples from a given layer must be older than the samples from a layer above (Biasi et al. 2002, Hilley and Young 2008). Dating of paleo earthquake records by trenching however has been a major challenge because of the difficulty in distinguishing cutting relationships of the faults from stratigraphic patterns (Akyüz et al. 2015). It needs sedimentary archives that are thin enough to access but thick enough to catch all of the paleo events. On the other hand, not all of the surface-rupturing earthquakes can be recognized by trenching methods (Yeats 2007). In some cases, destructive earthquakes may not produce any surface rupture or can only be manifested as distributed deformation (Atakan 2000). In slow deformation areas like intraplate domains, characteristics of long-term seismic release cannot be detected fully through paleoseismic trenching studies (Clark and McCue 2003). Also, a faster rate of sedimentation can cover event horizons with a thick pile of sediments which restrains the investigation of the paleoevents. One of the chief challenges of modern paleoseismic trenching investigations is the difficulty in finding datable material in the sedimentary archive. They could also have relatively poor temporal precision owing to the uncertainties associated with the relationship between the dated samples and their deposits (Fraser et al. 2010). There may also be insufficient and unsuitable sample material for dating due to the unfavourable environmental and/or sedimentological conditions. In addition, it is difficult to identify all individual earthquakes along fast-moving faults (especially at overlapping sections of neighbouring fault segments) because of 
the limitation of dating methods. Thus, there is an obvious need for complementary methods and techniques.

In the current study, we correlate U-Th age data of carbonate veins precipitated in co-seismic fissures with robust historical earthquake and paleoseismic data records along the 1939 Erzincan earthquake-rupture segment of the NAFZ (Figure 2b). U-Th ages are tested for the first time in the literature in relation to recurrence intervals, the size and epicentre distance of major Holocene earthquakes. Timing of fluid inflow events within the fracture systems are determined by U-Th dating of carbonate veins, which are considered to have precipitated from circulating fluids during and shortly after the Holocene earthquakes. Known records of the historical earthquake catalogues and previous dating results derived from the surrounding trench studies are compared with periods of the carbonate precipitation using the statistical evaluation of U-Th age distributions.

\section{Co-seismic Fluid Circulation on Active Fault Zones}

During interseismic periods, shallow and deep aquifers are relatively stable. However, during earthquakes changes occur in groundwater aquifers (Montgomery and Manga 2003, Wang et al. 2004). Elastic strain and compression can cause water level rise, whereas enhanced permeability can induce both the rise and fall of this level depending on the water pressure (Shi et al. 2018). In the case of a lesser pressure gradient in unconfined and shallow aquifer, the permeability increase may enhance downward flow and, consequently the water level falls (Montgomery and Manga 2003, Cutillo and Ge 2006) (Figure 1a). For example, during large-magnitude earthquakes $(\mathrm{M}=5-8)$ pore volume is increased and permeability is enhanced which induces downward groundwater flow, close to the monitoring wells (Parvin et al. 2014) (Figure 1). Additionally, the shear stress and elastic strain become zero at the ground surface and increase with depth (Seed and Idriss 1971) (Figure 1a). Thus, deep aquifers are loaded by larger elastic strain which causes a relatively large expulsion of depressurized $\mathrm{CO}_{2}$-rich hot waters.

Co-seismic fracture development and related vein precipitation during seismic release have long been known. Direct field evidence of this phenomena along active faults was first noticed by Sibson (1987) in the southern San Andreas Fault system, whereby major dilatational jogs extending throughout the seismogenic regime act as vertical pipe-like conduits for enhanced fluid flow. Precipitation of episodic neoformational minerals (mainly calcite) in the top 1-2 $\mathrm{km}$ of such dilatational jog structures is induced by the dynamic effects of the fault rupture. The cycle of episodic co-seismic carbonate precipitation was described by Uysal et al. (2007), Nuriel et al. (2012), Brogi and Capezzuoli (2014),Karabacak et al. (2017), and Williams et al. (2017), in detail, and involve: 1) opening/reopening of fractures due to seismic release, 2) simultaneous fluid circulation in fracture systems and expulsion of depressurized/supersaturated hotwater, 3) rapid precipitation of carbonate on both walls of the fracture (planar)until plugging of the 
fracture during the post-seismic period, 4) relatively unsaturated and slow fluid flow from shifting points along the sealed fracture (pipes) during interseismic period, and 5) repeating cycles through fault reactivations.

The internal structure of carbonate veins formed in alternated bands (Figure 1b)is closely linked to repeated fault reactivation (this can be compared with the Figure $3 \mathrm{~b}$ of Williams et al. 2017) that requires reopening of the previously sealed fractures within the bedrock, favouring temporary endogenic fluid circulation. With an alternative scenario in Figure $6 c$ of Capezzuoli et al. (2018), it is suggested that every band is made up of two main crystal associations that are juxtaposed: 1) whitish microcrystalline calcite that is related to abundant fluid inclusions with high- $\mathrm{CO}_{2}$ degassing of the co-seismic activity, and 2) light-transparent macrocrystalline elements that are precipitated at slow degassing rates during the time up to sealing (post-seismic). In both cases, each band of the vein represents a limited time interval postdating the earthquake (Figure $1 b)$.

There are two important issues to be considered in the comparison of carbonate precipitation with seismic release; the lower limit and upper limit. The former refers to the beginning of vein precipitation following an earthquake and the latter is related to how rapidly veins grow to the sampled thickness. Postseismic fluid flow has been shown to begin at modest levels a few days after the fault rupture (Muir-wood and King 1993) and supersaturated fluids circulating within the damaged rocks can rapidly precipitate calcite leading to deactivation of thermal springs (Brogi and Capezzuoli 2014). This, in turn, results information of banded carbonate veins in near-surface fractures as soon as possible after close-epicentral earthquakes. For example, Brogi and Capezzuoli (2014) documented for the first time direct co- and post-seismic effects of an $\mathrm{M=}$ 3.6 earthquake in Tuscany (Italy) leading to the occurrence of fluid flow along fissure-ridge travertine. Accordingly, the commencement of carbonate precipitation is argued to be almost simultaneous with the earthquake event, which could be used as a proxy for seismic records.

Improved U-series dating techniques helped demonstrate the role of carbonate veins in reconstructing the evolution of crustal dilatation (Altunel and Karabacak 2005) and seismic strain cycles (Uysal et al. 2007). Earlier studies showed comprehensively that travertine veins formed through the injection of overpressured hydrothermal fluids within earlier precipitated bedded travertines in association with latest Pleistocene seismic events (Uysal et al. 2009, Brogi et al. 2017). Williams et al. (2017) presented U-Th dating results of calcite veins along a normal fault zone, Rio Grande rift (New Mexico) that constrain a long-term recurrence interval in a range of $150 \mathrm{ka}$ to $550 \mathrm{ka} \mathrm{BP}$. Although all previous work rest on the inference that the fluid discharge events are directly related to seismic strain, this relationship has not been proven with the actual earthquake records until now.

There are several well-preserved fissure-ridge travertine sites along the NAFZ (Figures 2a and c, Table S1). Other examples of carbonate veins include fault-related fissures in the Aegean region 
(Turkey and Greece), the northern Apennines (Italy), and the Basin and Range province (USA) (e.g., Hancock et al. 1999, Altunel and Karabacak 2005, Uysal et al. 2011, Berardi et al. 2016, Brogi et al. 2017). Thus, carbonate veins could be of broad interest and have wide-ranging application in studies of active tectonics and in a variety of tectonic settings in the investigation of co-seismic records of active faults. In this study, we focused on one of these sites within an active plate-boundary transform fault zone.

\section{Evidence of Surface Rupturing Earthquakes}

Slip rates obtained from geodetic, geomorphic and geologic data yield a movement of about 18to $26 \mathrm{~mm} /$ year along the NAFZ (McClusky et al. 2000, Hubert-Ferrari et al. 2002, Kozaci et al. 2007). As a result of such high slip-rate strain accumulates over periods of time leading to a sequence of large-magnitude earthquakes (Figure 2a). The paleoseismic recurrence interval of this sequence in the western section of the NAFZ is estimated to range between 100 and 300 years (e.g. Klinger et al. 2003, Rockwell et al. 2009, Fraser et al. 2010). However, Hartleb et al. (2006) and Kozac1 (2008) stated that the eastern NAFZ does not always rupture in sequences similar to the twentieth-century cluster of the fault. For instance, Fraser (2009) suggested a bimodal recurrence interval with the modes at 100-400 and 900-1200 years for the Kelkit Valley segment of the NAFZ.

The Erzincan earthquake of 26 December 1939 was the first large event during the last century which created a rupture zone of about $360 \mathrm{~km}$ length, extending from the eastern end of the Erzincan Basin to the south of the Amasya province (Figure 2a) (Barka 1996, Zabc1 et al. 2011, Gürsoy et al. 2013). Just three years after, another devastating earthquake occurred near the western extent of the 1939 rupture segment (20 December 1942; Erbaa-Niksar Earthquake, Ms= 7.1) (Figure 2a). A 10-km-wide releasing step-over separates the rupture propagation of the 1939 and 1942 events (Barka et al. 2000). An earlier historical Anatolian Earthquake on 17 August 1668 has been reported to occur on the same segments with a probable rupture length of more than $400 \mathrm{~km}$ (Ambraseys and Finkel 1988, Zabc1 et al. 2011). Large historical earthquakes, including the well-documented 1939 and 1668 events, are reported along the NAFZ between Niksar and Erzincan basins. Supplementary Table S2 summarizes the macroseismic descriptions of large historical earthquakes which affected the studied region.

The 1939 rupture consists of five major geometric segments (i.e. Erzincan, Mihar-Tümekar, Ortaköy-Suşehri, Kelkit Valley and Ezinepazarı) (Barka 1996, Zabc1 et al. 2011, Fraser et al. 2012) (Figure 2b). The paleoseismplogical studies regarding the 1939 rupture segment are mainly concentrated on the Mihar-Tümekar, Ortaköy-Suşehri and Kelkit Valley geometric segments (Figure 2b) and they present a spatial distribution for the paleo events.

Along the Mihar-Tümekar segment three research groups have excavated several trenches (Hartleb et al. 2006, Kozaci et al. 2011, Fraser et al. 2012) (Figure 2b), where 1200 BC, 499 AD, 
1045 AD, and 1254 AD events were dated (Figure 3). Moreover, Fraser et al. (2012) provided evidence of the 1668 earthquake in the western part of the segment (Figure 3). In these studies, separate events of the 9th BC, 3rd BC, and 8th AD centuries were recorded which are not mentioned in the earthquake catalogues (Table S2). Hubert-Ferrari et al. (2012) showed that a sag-pond lake that setson the segment border towards the west yielded a reliable paleoseismic record obtained through the lake cores (Figure 2b). Radiocarbon dating on varved lake sediments reveals the evidence of the 1254 AD, 1668 AD, and 1939 AD historical earthquakes and another earthquake between $1400 \mathrm{AD}$ and 1600AD which was not documented before, along the NAFZ.

However, on the Ortaköy-Suşehri geometric segment Polat et al. (2012) have also identified paleo events that are not fully constrained by their dating results (Figure 3). The Kelkit Valley segment between the Suşehri and Niksar Basins is approximately $100 \mathrm{~km}$ long. Towards the west this segment is separated from the Ezinepazarı segment by westward bending of the fault zone and from the 1942 rupture by a releasing step-over (Figure 2b). In trenches opened at the eastern side of the study area, Zabc1 et al. (2011) evidence was found of three surface faulting earthquakes predating the 1939 event. In addition to the 1939 Erzincan earthquake, surface ruptures of previous earthquakes are interpreted to represent the $1045 \mathrm{AD}, 1254 \mathrm{AD}$, and 1668 AD events (Figure 3).Fraser (2009) presented paleoseismic trenching dates of the 499 AD and $1668 \mathrm{AD}$ earthquakes in the western part of the Kelkit Valley segment (Figures 1b and 4). In the same study, new data indicating the $23 \mathrm{rd} \mathrm{BC}, 20$ th BC, 9th BC, and 3rd BC century events were absent in earthquake catalogues (Figure 3). Therefore, given the presence of numerous earthquakes occurring in the vicinity of the study area, it should be verified whether these events are recorded by the fault-localized travertine carbonates.

\section{Sampling Site, Analytical Techniques and Geochronological Data}

\subsection{Reşadiye fissure-ridge travertine}

The Kelkit Valley geometric segment of the 1939 Earthquake rupture is represented by the narrowest morphology throughout the NAFZ (Figures $2 b$ and c). The Reşadiye site forms one of the widest parts of the segment with a maximum opening of $750 \mathrm{~m}$ in the N-S direction (Figure $2 c)$. The strike of the fault is N70W to the east of Reşadiye. Using focal mechanisms, the $S_{\text {Hmax }}$ axis was calculated to be in NW-SE direction for the region by the World Stress Map Project database WSM (Heidbach et al. 2016). The fault is interrupted around the Reşadiye town (Emre et al. 2012). It extends towards the west as two parallel branches in N75W direction (Figure 2c). This geometry of faulting is interpreted as a pull-apart basin with a rhomboidal geometry (Gürsoy et al. 2013). There are active hot springs along the well-developed fracture system.

The Reşadiye fissure-ridge type travertine occurs along the $\sim \mathrm{NW}$ - striking sigmoidal dilation fracture linked to the shear zone (Figures2c-inset and 4a). Z-shaped geometry of the fracture suggests that it is formed in a right-lateral shear zone as an extensional fracture (perpendicular to 
the minimum compressive stress). The general strike of the sigmoidal extent is parallel to the $\mathrm{S}_{\text {Hmax }}$ (Figure 2c-inset).

The main central fissure of the Reşadiye travertine ridge contains vertical carbonate vein (Figures $4 \mathrm{~b}, \mathrm{c}, \mathrm{d}$ and e). It extends about $650 \mathrm{~m}$ as a single vein. Vein width varies from a few cms to $1 \mathrm{~m}$, reaches maxima in central parts and there is no fracture opening along the vein centre.

There are also secondary fractures within the main fissure-ridge travertine. They occur especially in the central part and present geometrical similarities among themselves. Secondary fractures that are filled with carbonate material are mostly exposed vertically and in some cases they dip to about $70-80^{\circ}$. Their maximum length is up to a few tens of meters and widthsare of a few cms. A few of secondary fissuresthat also run parallel to the local $\mathrm{S}_{\mathrm{Hmax}}$ direction (N40-45W) cut the main vein at low angles. The shear zone controlling the sigmoidal deformation and extensional fracturing is parallel to the NAFZ. Moreover, the main fissure-ridge is in a few hundred meters distance to the last earthquake rupture (1939 Erzincan earthquake). Therefore, carbonate veins filling the fracture offer an excellent opportunity for the investigation of seismic records of the NAFZ along the Kelkit Valley.

We conducted sampling at three selected locations (Figure 2c, inset photo). First of all, we determined candidate veins that could be sampled from the whole width (wall to wall) or at least from wall to fissure centre. On the veins, we separated representative carbonate bands that were relatively thick, detritus-free and crystalline (see an example in Figures 5a-c).All bands were labelled in the field. Possible points for dating were signed on the samples to indicate the first precipitation sides (closer side of the band to fracture wall) (see an example in Figure 5d). Totally 22 carbonate bands were collected (Table 1).

L1 location (samples 1-8): This location was sampled (Figure 2c, inset photo) around the central part of the main ridge. 8 carbonate band samples were collected from 6 separate veins that filled the secondary fissures (Figure S1, Table 1). Banded travertine samples of 1, 2 and 3 were taken from a N45-50Wstriking vertical fissure vein. Samples 4 and 5 were collected from two parallel fissures in the same direction, whilst samples 6, 7 and 8 were from N55-60W striking fissures. Widths of carbonate bands vary from 1 to $5 \mathrm{~cm}$.

L2 location (samples 9-15): The location was sampled from a well-exposed part of the main vein (Figure 2c, inset photo). Sampling was done systematically from the whole width of the vein (wall to wall) (Figures4b, 4e and 5).7 banded travertine samples at N60-65W/80SW position were collected (Table 1). Widths of sampled carbonate bands range from 2 to $5 \mathrm{~cm}$.

L3 location (samples 16-22): This location was sampled from the main vein (Figure 2c, inset photo and Figure 4d). Sampling was done on the NE half of the symmetric bands, from the contact with the wall-rock towards the middle of the vein (Figure S2). 7 banded travertine samples at N50-55W/90 position were collected (Table 1). Widths of the bands are between 2 and $5 \mathrm{~cm}$. 


\subsection{U-Th geochronology}

Carbonate band samples collected along the Reşadiye fissure-ridge travertine were cut parallel to their deposition directions. Collected carbonate samples were polished in order to remove any weathered surfaces, and then cleaned ultrasonically in deionized water. Before the analysis two sets were prepared: One of the sets was used to investigate the whole rock mineralogy and microtexture by XRD and thin section petrography, respectively (Figures S3-S7). The sampled veins were unaltered and not coated by secondary minerals. The characteristics of the vein textures depended on the nucleation of the filling material, the growth kinetics, the kinematics of vein opening (or dilation), and the host rock geometry (Blenkinsop 2000). Based on the results of XRD and microscopy studies, collected carbonate samples are coarsely crystalline (Figures S3S7) and consist of almost $100 \%$ calcite minerals. Calcite fabrics are generally observed as long elongated and open columnar forms with frequent twinning and deformation.

For U-Th dating, carbonate vein samples of the second set were microdrilled from the immediate nearest location of the band to the fracture wall (see Figures 1b, S1d and S1f).The discontinuities between the bands (hiatus) are quite noticeable ensuring no contamination in adjacent generations (see Figure 5). We used 1-5 mm diamond drill bits to extract of calcite powder (see the text for the detailed geochemical treatment for U-Th analysis) (see more detail for the micro sampling process in supplementary data of Uysal et al. 2019). The size of the powdered subsamples varied from 20 to $200 \mathrm{mg}$ depending on the sample thickness and our ability to drill from the same vein layer (as the layer thicknesses change laterally, or a specific layer disappears due to replacement by another layer). These powders were used for sample digestion before UTh analysis. In some veins, we chipped the part of the vein immediate to the vein wall and powdered the chipped calcite in preference to microdrilling. Accordingly, we utilized $\sim 30 \%$ of a 1 -cm-thick vein sample, which corresponds to the deposition age of at least 1/3 of each band.

We dated 22 samples (Table S3) (see Table 1 for the summary of the age results). U-Th dating of the first 15 samples in Table 1 was carried out using a Nu Plasma multi-collector inductivelycoupled plasma mass spectrometer (MC-ICP-MS) at the Radiogenic Isotope Facility in the School of Earth and Environmental Sciences, The University of Queensland, following the chemical treatment procedures described in Cheng et al. (2000) and MC-ICP-MS analytical protocols described in Roff et al. (2013). Powdered sub-samples weighing 20-200 mg were completely dissolved in double-distilled concentrated $\mathrm{HNO}_{3}$ with a mixed ${ }^{229} \mathrm{Th}^{2}{ }^{233} \mathrm{U}$ tracer. After digestion, each sample was further treated with $\mathrm{H}_{2} \mathrm{O}_{2}$ to decompose trace amounts of organic matters (if any) and to facilitate complete sample-tracer homogenisation. $\mathrm{U}$ and Th were separated using conventional anion-exchange column chemistry using Bio-Rad AG 1-X8 resin. After stripping off the matrix from the column using double-distilled $7 \mathrm{~N} \mathrm{HNO}_{3}$ as eluent, $3 \mathrm{ml}$ of $2 \% \mathrm{HNO}_{3}$ and trace amounts of $\mathrm{HF}$ mixture were then used to elute both $\mathrm{U}$ and Th into test tubes which form aliquots ready for MC-ICPMS analyses. U and Th isotope ratios can be collected 
together as the samples in this study contain relatively low levels (sub-ppm) of U. The U-Th mixed solution was injected into the MC-ICP-MS through a DSN-100 desolvation nebuliser system with an uptake rate of around $0.12 \mathrm{ml}$ per minute. U-Th isotopic ratio measurement was performed on the MC-ICP-MS using a detector configuration to allow simultaneous

measurements of both $U$ and Th isotopes (Roff et al. 2013). The ${ }^{230} \mathrm{Th} /{ }^{238} \mathrm{U}$ and ${ }^{234} \mathrm{U} /{ }^{238} \mathrm{U}$ activity ratios of the samples were calculated using the decay constants given in Cheng et al. (2000). The non-authigenic ${ }^{230} \mathrm{Th}$ was corrected using an assumed bulk-Earth atomic ${ }^{230} \mathrm{Th} /{ }^{232} \mathrm{Th}$ ratio of 4.4 $\pm 2.2 \times 10^{-6}$. U-Th ages were calculated using the Isoplot 3.75 Program (Ludwig 2012).

U-Th analysis of the remaining 7 samples was done at the same laboratory on a VG Sector 54 TIMS following analytical protocols described in Zhao et al. (2001).

As the samples contain extremely low $\mathrm{U}(5-15 \mathrm{ppb})$ and have low U/Th ratios, they are very difficult to measure and many samples have very low ${ }^{230} \mathrm{Th} /{ }^{232} \mathrm{Th}$ activity ratios, resulting in large error magnifications after correction for non-radiogenic ${ }^{230} \mathrm{Th}$ based on the assumed BulkEarth ${ }^{230} \mathrm{Th} /{ }^{232} \mathrm{Th}$ activity ratio of $0.83 \pm 50 \%$ for the detrital Th component. Nevertheless, when we calculate the ratios of age errors to their corresponding corrected ages (see column 6 in Table 1), eight of the samples are found to yield an error ratio (the ratio of error value $(2 \delta)$ to corr. age, $\%$ ) over $64 \%$, defined by samples with the lowest measured ${ }^{230} \mathrm{Th} /{ }^{232} \mathrm{Th}$ activity ratios. However, the relative age errors of the other 14 samples are lower, varying from $9 \%$ to $38 \%$ and their measured ${ }^{230} \mathrm{Th} /{ }^{232} \mathrm{Th}$ activity ratios are higher.

\subsection{Statistical analyses}

The statistical distributions of U-Th ages are usually assessed using the relative probability plots calculated from the Isoplot 4.15 program (Ludwig 2012), which incorporates the 2-sigma age error range of all samples. The relative probability distribution of U-Th ages indicates that carbonate deposition occurred during different periods in the last 7 ka (Figure S8a). Similar age probability peaks were obtained when we use samples with more precise relative age errors (i.e., ages that have error ratio of $<38 \%$ ) (Figure $\mathrm{S} 8 \mathrm{~b}$ ). The probability plot shows 8 different age peaks (4770 BC, 1390 BC, 200 BC, 500 AD, 1040 AD, 1170 AD, 1430 AD, and 1760 AD) (Figure S8a), which are likely correlated with the earthquakes.

To assess the relationship between the two data sets (carbonate ages and earthquakes), we employed linear regression analysis. Table 2 presents the carbonate vein ages and earthquake records used for the correlation in this study. In the computation, the age results estimated from maximum peaks of the relative probability plot and earthquake catalogue records were compared. If no peak data are available on the probability plot, measured U-Th ages were considered (e.g. lines 17 and 18 in Table 2). Likewise, if no record exists in the earthquake catalogue, paleoseismic records are included in the calculation (e.g. lines 17 and 18 in Table 2). Table S4 summarizes the data sets and statistical parameters of the regression analysis. The mean 
and standard deviation values of both data sets are found quite close (Figure S9). The regression plot reveals a significant correlation at $95 \%$ confidence between the two time series (with pvalue of 0.000002 ).

\section{Discussion}

\subsection{Restrictions on regional paleoseismic records}

Paleoseismological investigations are the common way to characterize past earthquake records that help to create a database for seismic hazard studies. However, there have been some major challenges in reconstructing the most complete seismic history. Main drawbacks of paleoseismic trenching include insufficient trench depth for long-term records, variability and uncertainty in deposit frequency and thickness, complexity of fault geometries and fault-sediment relationships in trench exposures, and more complexity logistically in remote locations.

Figure 3 summarizes the records of the earthquake catalogues and paleoseismic data from trench studies along the 1939 Earthquake rupture zone. Although the number of paleoseismological studies in all segments is not sufficient, assessment of data from the neighbouring segments (e.g. Mihar-Tümekar, Ortaköy-Suşehri and Kelkit Valley segments) reveals the existence of several gaps in the record. For example, Fraser et al (2012) failed to provide evidence of the 1045 AD earthquake, although the event was dated in neighbouring studies (Figure 3). There are difficulties in distinguishing the field relationships of the earthquake ruptures commonly associated with proper selection of the trench location and error precision of the dating methods. In some cases the depth reached in a trench may be insufficient. For example, even though the data presented in the neighbouring studies are up to 2000 BC (e.g. Fraser 2009), the 1045 AD earthquake was the earliest data recorded by Zabc1 et al. (2011) (Figure 3). Paleoseismic dating becomes meaningful if the data are compared with events known from the historical earthquake records. However, there may also be some gaps or paralogisms in the historical earthquake records. For instance, although the 17 August 1668 AD earthquake is thought to have a probable rupture length of more than $400 \mathrm{~km}$ (Ambraseys and Finkel1988), other earthquake catalogues suggest a series of events (occurred between 1666 AD and 1668 AD), rather than one large earthquake (e.g., P1nar and Lahn 1952, Ergin et al. 1967) (Table S2). Furthermore, although an earthquake was recorded in all segments in the 3rd century BC (e.g. Hartleb et al. 2006, Fraser 2009), earthquake catalogues show no reliable record before the $343 \mathrm{AD}$ event (Table S2). The only event close to this time is reported at $1200 \mathrm{~s} \mathrm{BC}$, which is attributed to a sequence of earthquakes along the NAFZ that destroyed major cities at the time of transition from the Bronze Age to the Iron Age (Nur and Cline 2000). In short, regional paleoseismic records are still scarce which urgently need to be increased by new data sets with comparable results.

\subsection{Implication of $U$-Th dating for paleoseismic records: time, size and distance}


Our age data extracted from carbonate veins indicate the presence of precipitation over at least 8 different periods in the last 7000 years along the Kelkit Valley. The maximum probability of these periods is clustered around $4770 \mathrm{BC}, 1390 \mathrm{BC}, 200 \mathrm{BC}, 500 \mathrm{AD}, 1040 \mathrm{AD}, 1170 \mathrm{AD}$, $1430 \mathrm{AD}$, and $1760 \mathrm{AD}$ (Figure S8a, see the calculated uncertainties in Table 2). Among the entire data set, particularly those with reliable results, there is no noticeable change in the maximum peak values (Figure S8b).

Table 2 compares the entire age data with earthquake records. Overall assessment of the age correlations between U-Th results, probability peaks, historical earthquakes and trenching records could imply that the apparent correlation might not be accidental. The youngest event peak known from the carbonate dating is represented by the 1760 AD age (Figure S8). The peak within the range of analytical error is in line with the events known from trenching along the Kelkit Valley (Fraser 2009, Zabcı et al. 2011) and Mihar-Tümekar segments (Fraser et al. 2012) (Figure 3 and Table 2). Although the earthquake catalogues report a devastating event on $1783 / 84 \mathrm{AD}$, all previous trenching dates were attributed to the $1668 \mathrm{AD}$ Anatolian earthquake. The uncertainty around the youngest U-Th peak is 150 years (Table 2). Thus, even if not precisely distinguished, this peak could correspond to the major 1668 AD or 1783/84 AD events known from the historical earthquake. However, the epicentre and the rupture length of the 1668 AD event has been debated (Pinar and Lahn 1952, Ergin et al. 1967, Ambraseys and Finkel, 1988, Zabc1 et al. 2011), since they might be masked by additional earthquake series on different segments.

The peak at $1430 \mathrm{AD}$ that is represented by two carbonate samples with more precise relative age errors, corresponds to the most prominent event peak obtained from the carbonate dating (Figure S8, Table 2). This peak is consistent, within the range of analytical error, with the results of all paleoseismic trenching studies conducted to the east of Reşadiye (Hartleb et al. 2006, Kozac1 et al. 2011, Zabc1 et al. 2011, Fraser et al. 2012). The event dated in these trenches was attributed to the $1254 \mathrm{AD}$ earthquake in the historical earthquake records. However, there is no data showing that $1254 \mathrm{AD}$ earthquake ruptured the fault segment to the west of Reşadiye. This earthquake is not within the error range of the $1430 \mathrm{AD}$ event peak obtained from the carbonate dating. Nevertheless, Hubert-Ferrari et al. (2012) provided evidence for an earthquake between $1400 \mathrm{AD}$ and $1600 \mathrm{AD}$ through coring of sag-pond sediments on the border of Mihar-Tümekar and Ortaköy-Suşehri segments (Figure 2b). Therefore, the 1430 AD event peak revealed from the carbonate U-Th dating (Figures 4 and S8a) might belong to another event recognized in the historical earthquake records (e.g. 1419/1422 AD earthquake).

The peak of 1170 AD is not easily distinguished from the 1040 AD event indicated by U-Th dating (Figure S8). However, it could be consistent with the 1166/68 AD event known from earthquake catalogues. The $1040 \mathrm{AD}$ event peak revealed from the carbonate dating mostly coincides with the record of the 1045 AD event in the historical earthquake records (Figure 3), which was also dated in trenches to the east of Reşadiye (Hartleb et al. 2006, Kozac1 et al. 2011, 
Zabc1 et al. 2011). Accordingly, the surface rupture of the 1045 AD earthquake may have reached at least the Reşadiye area in the west.

The $500 \mathrm{AD}$ event peak of the carbonate dating is consistent with the 499 ADevent in the historical earthquake records which has been dated in most trenching studies (Figure 3 and Table 2).

The $200 \mathrm{BC}$ peak of the U-Th carbonate age distribution can be correlated with trenching dates between the 5th BC and 1st BC centuries. Hartleb et al. (2006), Fraser (2009) and Polat et al. (2012) recorded an event corresponding to this time interval (Figure 3). Although earthquake catalogues do not report any seismic activity for this period, the $200 \mathrm{BC}$ carbonate peak is compatible with seismic events documented in the trenches within analytical error.

The dated 1390 BC peak coincides with the 1200 BC historical earthquake record (Nur and Cline 2000). Hartleb et al. (2006) and Fraser et al. (2012) also recorded a trenching date matching this time interval along the Mihar-Tümekar segment.

The oldest dated event is represented by the peak at 4770 BC (Figure S8a). Earthquake catalogues and paleoseismic trenching studies are not able to indicate any event around this peak, since catalogues may not cover this time span. At least six of the eight carbonate ages correspond to the events reported in the earthquake catalogues (1200 BC, 499 AD, 1045 AD, 1166/1168 $\mathrm{AD}, 1419 / 22 \mathrm{AD}, 1783 / 84 \mathrm{AD}$ earthquakes). Moreover, within the range of analytical error, six of these eight ages (1390 BC, 200 BC, 500 AD, 1040 AD, 1430 AD, and 1760 AD) coincide with the events dated in the trenches.

The statistical distributions of our age data on the relative probability plots do not yield any peak around some major earthquakes (i.e. 1254 AD, 1939 AD earthquakes), which can be possibly explained by the following: 1) based on direct observations on the co- and post-seismic effects, Brogi and Capezzuoli (2014) suggested that fluid discharge and associated banded travertine growth within a vein does not necessarily occur along the whole fissure during each earthquake. Hence, we may have missed the veins that were emplaced following the 1939 earthquake, 2) carbonate precipitation related with co-seismic fluid influx may not occur during every event due to the changes in geological and/or rheological conditions (such as the changing of fluid pathways or mixing of $\mathrm{CO}_{2}$-bearing fluids with unsaturated surface waters) (e.g. Montgomery and Manga 2003, Wang et al. 2004, Shi et al. 2018), 3) ongoing fluid circulation during a seismic event may be overlapped with another fluid circulation event triggered by a close-time earthquake until plugging of the fracture and4)the epicentres of the 1939 earthquake and the 1668 AD earthquake are proposed as being 200 km (Dewey 1976, Barka 1996, Zabc1 et al. 2011, Gürsoy et al. 2013) and $300 \mathrm{~km}$ away, respectively from the study area (Fraser et al. 2009, 2012, Zabc1 et al. 2011). For distant earthquakes, the elastic strain is relatively small (Seed and Idriss 1971) and enhancement of pore connectivity and permeability may be negligible over the depth range (Figure 1a). For example, Shi et al. (2018) documented co-seismic discharge and temperature decreases in hot springs with an epicentre distance of over $300 \mathrm{~km}$. As a result, rises 
in groundwater level would occur most frequently in the shallow and deep aquifers where the elastic strain is intense (Parvin et al. 2014) and this induces relatively less expulsion of depressurised $\mathrm{CO}_{2}$-rich hot waters. Deep waters that rise through the well-developed fracture systems are diluted by the thick water column within the shallow aquifer (Figure 1a). Banded carbonate precipitation may not occur within fractures at remote epicentres $(>200-300 \mathrm{~km})$ and therefore, unless otherwise indicated, it cannot be assumed that the proposed method reveals all paleoseismic records and further studies are warranted through more detailed and improved sampling techniques.

There has also been a discussion among the paleoseismologists as what a minimum magnitude would be detected through a paleoseismological study (Akyuz et al. 2015). Therefore, the relation of the magnitude with co-seismic carbonate vein formations and the associated fluid inflow process remains to be understood. The comparison of our data with the results of conventional paleoseismic trenching studies, as displayed in Figure 3, implies that the U-Th ages of the carbonate veins are synchronized with all of the surface rupture findings, except for the 1939 earthquake (surface rupturing events for strike-slip faults are proposed as $M>5$, Wells and Coppersmith, 1994). Moreover, this consistency is also observed with the historical earthquake records (I>VII). However, there is another probability peak (1430 AD) associated with the softsediment deformation spanning from $1330 \mathrm{AD}$ to1530 AD (see in section 4.2), which reflects a moderately sized earthquake without any surface rupturing (I $>$ VI). Thus, considering the uncertainty of the seismic sources and the results of our data, it may be argued that the coseismic carbonate precipitations might record the earthquakes with intensity above VI.

\subsection{Growth rates of the carbonate bands and time span of co-seismic fluid circulations}

The duration of co-seismic fluid circulation depends on the volume of saturated water, nearsurface deposits, and the patterns of seismically induced strain (Montgomery and Manga 2003). The time span of the circulation controls the thickness of each carbonate band. Based on the age of central and outer alternated bands in a vein, growth rates of individual fractures were calculated in the range between 0.01 and $0.11 \mathrm{~mm} /$ year in different tectonic domains (Altunel and Karabacak 2005, Mesci et al. 2008, Karabacak et al. 2017). However, these studies have not taken into consideration the paraconformity (hiatus) between the alternated bands, which may correspond to interseismic periods (Figure 1b). These calculations estimated the rate of dilatation on the fracture rather than the precipitation rate. Similarly, for the assessment of minimum growth rate in the study area, supporting data S10 shows the age results of sampling along the carbonate veins from location L2. Considering the relationship between the age results of alternated bands from centre to the fissure wall, it can be concluded that carbonate bands around Reşadiye site have been precipitating at a minimum rate of $0.03 \mathrm{~mm} / \mathrm{year}$. Thus, if we consider 
the paraconformity (hiatus) between the alternated bands, the growth rate of each band should be much higher.

In a different tectonic domain (Aegean extensional region), Uysal et al. (2007) made an attempt to precisely date a single band with a thickness of $20 \mathrm{~cm}$ that shows no growth discontinuities (hiatuses) thus reflecting a continuous precipitation. It yielded, within analytical uncertainty, a 400 year precipitation period (see Figure 5a in Uysal et al. 2007). Based on this data, the growth rate of each carbonate bands in fractures could reach maximum of $0.5 \mathrm{~mm} / \mathrm{year}$. Therefore, we can infer that time span of a 1-cm-thick carbonate band precipitation changes between 20 and 300 years.

In our sampling strategy, the collected carbonate bands were micro-drilled and/or chipped from immediately nearest location to the fracture wall (see in section 4.2). Accordingly, we utilized about $30 \%$ of each band, so that our error margin would be less than $1 / 3$ of the whole precipitation time. This could be attributed to the fact that the resolution of our results for $\mathrm{cm}-$ scale carbonate bands is less than a few decades.

\subsection{Comments on the recurrence interval}

The contribution of historical earthquake records to the examination of the Paleoseismic recurrence interval in a region is restricted chiefly because of the lack of reliable catalogues. Despite all of its deficiencies, paleoseismic trenching is almost the only way to reveal important faulting parameters, including the recurrence interval.

Constraints on the paleoseismic recurrence interval along the NAFZ are subject to debate and it is estimated in the range of 100 to 1200 years (e.g. Klinger et al. 2003, Hartleb et al. 2006, Kozac1 2008, Fraser 2009, Rockwell et al. 2009, Fraser et al. 2010). This is attributed by Fraser et al. (2010) to the interaction with other fault structures or incomplete paleoearthquake records, which necessitate the collection of more precise Paleoseismic data.

Since carbonate veins are likely to occur due to the release of depressurised $\mathrm{CO}_{2}$-rich hot waters during seismic events and they have a resolution less than a few decades for $\mathrm{cm}$-scale, our results on the 1939 rupture segment contribute to the investigation of the paleoseismic recurrence interval with new supplementary data. To illustrate, although no event has been mentioned in the earthquake catalogues, the carbonate U-Th age peak at around $200 \mathrm{BC}$ could be correlated with the data derived from trenching studies. Also, the oldest event of $4770 \mathrm{BC}$ is dated for the first time through the U-Th method. Thus, the events at about $200 \mathrm{BC}$ and $4770 \mathrm{BC}$ should be taken into account in future trenching studies for earthquake recurrence time calculations of the region. Although there are other carbonate ages (i.e. samples 15-20, Table 2), our age data is insufficient to fill the gap between the $200 \mathrm{BC}$ and $4770 \mathrm{BC}$ event peaks, probably due to the high errors of U-Th ages (Table 2). 
Our data from Reşadiye indicate at least eight vein precipitation events during the last 7000 years. Age results and probability peaks for the AD times show more frequent records for the carbonate precipitation. Until the latest event precipitation of carbonate veins shows a recurrence interval with the mode at 130-330 years for the last millennium (1040 AD, $1170 \mathrm{AD}, 1430 \mathrm{AD}$, and $1760 \mathrm{AD}$ peaks). This finding is consistent with the paleoseismic recurrence interval in the western NAFZ (e.g. Klinger et al. 2003, Rockwell et al. 2009, Fraser et al. 2010). However, considering the last 2200 years, the precipitation interval becomes wider with a mode about 130700 years (200 BC, $500 \mathrm{AD}, 1040 \mathrm{AD}, 1170 \mathrm{AD}, 1430 \mathrm{AD}$, and $1760 \mathrm{AD})$. The increasing interval among the older dates could either be due to the higher variability in the recurrence interval or the lack of carbonate vein records. These evidence indicate that real recurrence intervals may be obscured by some phenomena that include: 1) despite the existence of a bimodal recurrence interval as suggested by Fraser (2009), the difference between the episodic modes is smaller than expected, 2) the data revealing a bimodal recurrence interval for the eastern NAFZ has not yet been collected, thus it is too early to assert the applicability of such a model with carbonate veins, or 3) carbonate records not only correspond to the surface-rupturing earthquakes, but co-seismic precipitation also taking place during moderate earthquakes that have not been recorded by the paleoseismic trenching.

Eventually, as listed in the following, there might be some important challenges of using this method solely as a paleoseismological technique:

1. Since the carbonate bands may not be uniform along the entire fracture (Brogi and Capezzuoli 2014), one crosscut of a vein could be insufficient for reconstructing the whole Paleoseismic history of an area.

2. Even if the fluid discharge and related carbonate precipitation start simultaneously with the earthquake (Muir-wood and King 1993, Montgomery and Manga 2003, Brogi and Capezzuoli 2014), the time it takes a co-seismic band to reach its maximum thickness depends on several variables (Altunel and Karabacak 2005, Mesci et al. 2008, Karabacak et al. 2017). Therefore, it is important that dating should be performed from the closest section of each band to the fracture wall (i.e., the plane where the precipitation first starts, Williams et al. 2017, Capezzuoli et al. 2018).

3. Although each alternate band in a vein is in close relation with repeated fault reactivation, each vein may not record all seismic releases around the region. Firstly, for a good co-seismic carbonate record to be created the earthquake must have an intensity (I $>$ VI, like our $1430 \mathrm{AD}$ peak) to allow the opening of the planar fracture and secondly, have a close epicentre ( $d<200$ $\mathrm{km}$, unlike $1668 \mathrm{AD}$ and $1939 \mathrm{AD}$ events) that will allow permeability enhancement (Parvin et al. 2014, Shi et al. 2018).

Therefore, in fast-moving domains, the method of dating vein carbonates may be suggested only as a supplementary tool to trenching to fill the gaps in historical earthquake records and Paleoseismic data. Nevertheless, U-Th dating of carbonate veins is a good candidate in 
providing long-term records of seismicity, particularly prehistoric, late Pleistocene and early Holocene events which cannot be dated easily by traditional paleoseismic trenching methods, especially in slow deformation regions (like intraplate faults).

\section{Conclusions}

We present U-Th age distributions of co-seismic carbonate veins along the eastern segments of the NAFZ and investigate specific records of the seismic release during the Holocene. Our data show that historical earthquakes could be satisfactorily dated with associated carbonate precipitation. The main outputs of this study are outlined below:

1. Carbonate vein precipitation associated with $\mathrm{CO}_{2}$-rich fluid flow along the Kelkit Valley segment of the NAFZ intensified at least eight times during the last 7000 years.

2. At least six of the periods correspond to the $1200 \mathrm{BC}, 499 \mathrm{AD}, 1045 \mathrm{AD}, 1166 / 1168 \mathrm{AD}$, $1419 / 22 \mathrm{AD}$, and 1783/84 AD events that were reported in earthquake catalogues. The last carbonate peak immediately postdates a major seismic event recorded in this region (1668 AD earthquake). Two other carbonate precipitation peaks are recognized at around $200 \mathrm{BC}$ and 4770 $\mathrm{BC}$, which were not reported in the earthquake catalogues.

3. Recurrence of carbonate precipitation ranging from 130 to 330 years for the last millennium is consistent with the previously proposed paleoseismic recurrence interval for the western NAFZ (i.e. 100-300 years). Considering the last two millennia, the recurrence interval becomes much wider varying from 130 to 700 years.

Although further studies are needed to evaluate the statistical significance of the age correlations, periods of carbonate precipitation inferred from U-Th age distributions in active fault zones are comparable with historical earthquake records and paleoseismic data of the earthquake events. Carbonate precipitations may record the earthquakes that have relatively close epicentre $(\mathrm{d}<200$ $\mathrm{km}$ ) and high intensity (I>VI). U-Th ages of the carbonates precipitated in seismically active regions may be a supplementary tool in establishing the Holocene earthquake records and a strong candidate for late Pleistocene paleoseismology.

\section{Acknowledgements}

This research was supported by the Scientific and Technical Research Council of Turkey (TUBITAK) (102Y034 and 114Y544), Eskisehir Osmangazi University Research Foundation (2017-1916), and Co-Funded Brain Circulation Scheme (Co-Circulation Scheme) granted to I. T. Uysal. Appreciation is extended to George Hilley for his indispensable suggestions on the earlier versions of the manuscript. We are grateful to Peter Gold and Randolph Williams for their constructive comments and suggestions that significantly improved the manuscript. We greatly 
acknowledge Andrew Todd for English editing of our manuscript. Data used in this manuscript can be found in the supporting information.

\section{References}

Akyüz, H.S., Karabacak, V., Zabcı, C. (2015). Paleoseismic Trenching, in Michael Beer, Ioannis A. Kougioumtzoglou, Edoardo Patelli, Ivan Siu-Kui Au eds., Encyclopedia of Earthquake Engineering, Springer Publications, doi: 10.1007/978-3-642-36197-5_107-1, isbn: 978-3642-36197-5.

Allen, C.R. (1986). Seismological and paleoseismological techniques of research in active tectonics. In Active Tectonics: Studies in Geophysics (R.E. Wallace Chairman, Ed.), pp. 148-154. National Academy Press, Washington, DC.

Altunel, E., Karabacak, V. (2005). Determination of horizontal extension from fissure-ridge travertines: a case study in the Denizli Basin, southwestern Turkey, GeodinamicaActa, 18/3-4 (2005) 333-342.

Ambraseys, N.N. (2009). Earthquakes in the Mediterranean and Middle East: A Multidisciplinary Study of Seismicity up to 1900, Cambridge University Press, Cambridge, UK, 947 pp.

Ambraseys, N.N., Finkel, C.F. (1988). The Anatolian Earthquake of 17 August 1668. In: Lee, W.H.K., Meyers, H. \& Shimazaki, K. (eds), Historical Seismograms and Earthquakes of the World. Academic Press, San Diego, 173-180.

Ambraseys, N.N., Finkel, C.F. (1995). The Seismicity of Turkey and Adjacent Areas: A Historical Review, 1500-1800, Istanbul, Turkey, 240 pp., isbn: 975-7622-38-9.

Ambraseys, N.N., Jackson, J. (1998). Faulting associated with historical and recent earthquakes in the eastern Mediterranean region, Geophys. J. Intl., 133, 390-406.

Atakan, K. (2000). Uncertainties in paleoseismology: Implications for the earthquake recurrence database. in: K.Okumura, K.Takada and H.Goto (Eds.) Active Fault Research for the New Millenium. Letter Press Co. Ltd., Hiroshima, Japan. pp. 5-10.

Barka, A.A. (1996). Slip distribution along the North Anatolian Fault associated with the large earthquakes of the period 1939 to 1967, B. Seismol. Soc. Am., 86, 1238-1254. 
Barka, A.A., Akyüz, S.H., Cohen, H.A., Watchorn, F. (2000). Tectonic evolution of the Niksar and Tasova-Erbaa pull-apart basins, North Anatolian Fault Zone: their significance for the motion of the Anatolian block, Tectonophysics, 322, 243-264.

Berardi, G., Vignaroli, G., Billi, A., Rossetti, F., Soligo, M., Kele, S., Baykara, M.O., Bernasconi, S.M., Castorina, F., Tecce, F., Shenet, C.C. (2016). Growth of a Pleistocene giant carbonate vein and nearby thermogene travertine deposits at Semproniano, southern Tuscany, Italy: estimate of CO2 leakage, Tectonophysics, 690, 219-239.

Biasi, G.P., Weldon, R.J., Fumal, T.E., Seitz, G.G. (2002). Paleoseismic event dating and the conditional probability of large earthquakes on the southern San Andreas Fault, California, Bull.Seismol. Soc. Am., 92, 2761-2781.

Blenkinsop T.G. (2000). Recognition of Deformation, Microstructures and Mechanisms in Rocks.Chapman\&Hall., isbn: 978-0-412-73480-9.

Brogi, A., Capezzuoli, E. (2014). Earthquake impact on fissure-ridge type travertine deposition, Geological Magazine, 151, 1135-1143.

Brogi, A., Capezzuoli, E., Kele, S., Baykara, M.O., Shen, C.C. (2017). Key travertine tectofacies for neotectonics and palaeoseismicity reconstruction: effects of hydrothermal overpressured fluid injection, Journal of the Geological Society, 174(4), 679.

Bronk-Ramsey, C. (2014). Radiocarbon dating in paleoseismology, in Beer, M., Kougioumtzoglou, I.A., Patelli, E., Siu-Kui Au, I., editors, Encyclopedia of earthquake engineering: Springer Berlin Heidelberg, p. 1-11.

Capezzuoli, E., Ruggier, G., Rimondi, V., Brogi, A., Liotta, D., Alçiçek, M.C., Alçiçek, H., Bülbül, A., Gandin, A., Meccheri, M., Shen, C-C., Baykara, M.O. (2018). Calcite veining and feeding conduits in a hydrothermal system: Insights from a natural section across the Pleistocene Gölemezli travertine depositional system (western Anatolia, Turkey), Sedimentary Geology, 364, 180-203.

Cheng, H., Edwards, R., Hoff, J., Gallup, C., Richards, D., Asmerom, Y. (2000). The half-lives of uranium-234 and thorium-230, Chem. Geol., 169, 17-33.

Clark, D., McCue, K. (2003). Australian paleoseismology: towards a better basis for seismic hazard estimation, Annals of Geophysics, 46(5), 1087-1105.

Cutillo, P.A., Ge, S. (2006). Analysis of strain-induced groundwater fluctuations at Devise Hole, Nevada, USA, Geofluids, 6, 319-333.

Dewey, J.W. (1976). Seismicity of Northern Anatolia, Bulletin of the Seismological Society of America, 66, 843-868.

This article is protected by copyright. All rights reserved. 
Emre, Ö.,Duman, T.Y., Kondo, H., Özalp, S., Elmac1, H. (2012). 1:250,000 Scale Active Fault Map Series of Turkey, Tokat (NK 37-13) Quadrangle. Serial Number: 35, General Directorate of Mineral Research and Exploration, Ankara-Turkey.

Ergin, K., Güçlü, U., Uz, Z. (1967). Earthquake Catalogue of Turkey and Nearby Regions (from 11 AD to 1964 BC). ITU Mine Faculty Press, İstanbul

Fraser, J.G. (2009). Four new paleoseismic investigations on the North Anatolian Fault, Turkey, in the context of existing data, PhD thesis, Univ. Libre de Bruxelles, Belgium, Brussels, $284 \mathrm{pp}$.

Fraser, J.G., Hubert-Ferrari, A., Verbeeck, K., Garcia-Moreno, D., Avşar, U., Maricq, N., Coudijzer, A., Vlamynck, N., Vanneste, K. (2012). A 3000-year record of surfacerupturing earthquakes at Günalan: variable fault-rupture lengths along the 1939 Erzincan earthquake-rupture segment of the North Anatolian Fault, Turkey, Annals of Geophysics, $55,5,895-927$.

Fraser, J.G., Vanneste, K., Hubert-Ferrari, A. (2010). Recent behavior of the North Anatolian Fault: Insights from an integrated paleoseismological data set, J. Geophys. Res., 115, B09316; doi:10.1029/2009JB006982.

Gray, H.J., Mahan, S.A., Rittenour, T., Nelson, M. (2015). Guide to luminescence dating techniques and their applications for paleoseismic research. In: Lund, W.R. (Ed.), Proceedings Volume, Basin and Range Province Seismic Hazards Summit III Utah Geological Survey Miscellaneous Publication 15-5. Utah Geological Survey, Salt Lake City.

Guidoboni, E., Comastri, A. (2005). Catalogue of earthquakes and tsunamis in the mediterranean area from the 11th to the 15th century, IstitutoNazionale di Geofisica e Vulcanologia, Bologna, $1037 \mathrm{pp}$.

Guidoboni, E., Comastri, A., Traina, G. (1994). Catalogue of Ancient Earthquakes in the Mediterranean Area up to the 10th Century, 504 pp., IstitutoNazionale di Geofisica e Vulcanologia, Rome.

Gürsoy, G., Tatar, O., Akpınar, Z., Polat, A., Mesci, L., Tunçer, D. (2013). New observations on the 1939 Erzincan Earthquake surface rupture on the Kelkit Valley segment of the North Anatolian Fault Zone, Turkey, Journal of Geodynamics, 65, 259-271.

Hancock, P.L., Chalmers, R.M.L., Altunel, E., Çakır, Z. 1999. Travitonics: using travertines in active fault studies, Journal of Structural Geology, 21, 903-916.

Hartleb, R.D., Dolan, J.F., Kozacı, O., Akyüz, H.S., Seitz, G.G. (2006). A 2500-yr-long paleoseismologic record of large, infrequent earthquakes on the North Anatolian fault at Cukurcimen, Turkey, Bull. Seismol.Soc. Am., 118, 823-840; doi:10.1130/B25838.1. 
Heidbach, O., Custodio, S., Kingdon, A., Mariucci, M.T., Montone, P., Müller, B., Pierdominici, S., Rajabi, M., Reinecker, J., Reiter, K., Tingay, M., Williams, J., Ziegler, M. (2016). Stress Map of the Mediterranean and Central Europe 2016. GFZ Data Services. http://doi.org/10.5880/WSM.Europe2016.

Hilley, G.E., Young, J.J. (2008). Deducing Paleoearthquake Timing and Recurrence from Paleoseismic Data, Part I: Evaluation of New Bayesian Markov-Chain Monte Carlo Simulation Methods Applied to Excavations with Continuous Peat Growth, Bull. Seismol. Soc. Am., 98; doi:10.1785/0120020077.

Hubert-Ferrari, A., Armijo, R., King, G., Meyer, B., Barka, A.A. (2002). Morphology, displacement, and slip rates along the North Anatolian Fault, Turkey, J. Geophys. Res., 107; doi:10.1029/2001JB000393.

Hubert-Ferrari, A., Avsar, U., El Ouahabi, M., Lepoint, G., Martinez, P., Fagel, N., (2012). Paleoseismic record obtained by coring a sag-pond along the North Anatolian Fault (Turkey), Annals of Geophysics, 55, 5, 929-953.

Hubert-Ferrari, A., Barka, A.A., Jacques, E., Nalbant, S., Meyer, B., Armijo, R., Tapponnier, P., King, G.C.P. (2000).Seismic hazard in the Marmara Sea region following the 17 August 1999 Izmit earthquake, Nature, 404, 269-273.

Karabacak, V., Uysal, İ.T., Ünal-İmer, E., Mutlu, H., Zhao, J-X.(2017). U-Th age evidence from carbonate veins for episodic crustal deformation of Central Anatolia Volcanic Province, Quaternary Science Reviews, 177, 158-172.

Klinger, Y., Sieh, K., Altunel, E., Akoglu, A., Barka, A.A., Dawson, T., Gonzalez, T., Meltzner, A., and Rockwell, T. (2003).Paleoseismic evidence of characteristic slip on the western segment of the North Anatolian Fault, Turkey, Bull. Seismol. Soc. Am., 93(6), 2317-2332, doi:10.1785/0120010270.

Kondorskaya, N.V., Ulomov, V.I. (1999). Special Catalogue of Earthquakes of the Northern Eurasia (SECNE). http://www.seismo.ethz.ch/gshap/neurasia/nordasiacat.txt, Access date: 25.01.2009

Kozac1, Ö. (2008). Constancy of strain release rates along the North Anatolian Fault, $\mathrm{PhD}$ thesis, 174 pp, Univ. of South. Calif., Los Angeles

Kozac1, Ö., Dolan, J.F., Finkel, R.C., Hartleb, R. (2007). Late Holocene slip rate for the North Anatolian Fault, Turkey, from cosmogenic 36Cl geochronology: Implications for the constancy of fault loading and strain release rates, Geology, 35(10), 867-870, doi:10.1130/G23187A.1.

Kozac1, Ö., Dolan, J.F., Yonlu, O., Hartleb, R.D. (2011). Paleoseismologic evidence for the relatively regular recurrence of infrequent, large-magnitude earthquakes on the eastern North Anatolian fault at Yaylabeli, Turkey, Lithosphere, 3, 37-54; doi:10.1130/L118.1 
Ludwig, K.R. (2012). User's Manual for Isoplot 3.75: A Geochronological Toolkit for Microsoft Excel, Berkeley Geochronology Centre, Special Publication No. 5, 75pp.

McCalpin, J.P. (2009). Paleoseismology (2nd ed.). Amsterdam: Academic Press.

McClusky, S.C., Balassanian, S., Barka, A., Ergintav, S., Georgie, I., Gurkan, O.,Hamburger,M., Hurst, K., Kahle, H., Kastens, K., Kekelidse, G., King, R., Kotzev, V., Lenk, O.,Mahmout, S., Mishin, A., Nadaria, M., Ouzounis, A., Paradisissis, D., Peter, Y., Pirilepin, M., Reilinger, R.E., Şanli, I., Seeger, H., Teableb, A., Toksöz, N., Veis, V. (2000). Global Positioning System constraints on plate kinematics and dynamics in the eastern Mediterreanen Caucasus, Journal of Geophysical Research, 105, 5695-5719.

Mesci, B.L., Gürsoy, H., Tatar, O. (2008). The evolution of travertine masses in the Sivas area central Turkey) and their relationships to active tectonics, Turkish Journal of Earth Sciences, 17(2), 19-240.

Montgomery, D.R., Manga, M. (2003). Stream flow and water well responses to earthquakes, Science, 300, 2047-2049.

Muir-wood, R., King, G.C.P. (1993). Hydrological signatures of earthquake strain, Journal of Geophysical Research, 98, 22035-22068.

Nur, A., Cline, E.H. (2000). Poseidon's horses: Plate tectonics and earthquake storms in the Late Bronze Age Aegean and Eastern Mediterranean, Journal of Archaeological Science, 27, 43-63.

Nuriel, P., Rosenbaum, G., Zhao, J.-X., Feng, Y., Golding, S.D., Villemant, B., Weinberger, R. (2012). U-Th dating of striated fault planes, Geology, 40, 7, 647-650.

Parvin, M., Tadakuma, N., Asaue, H., Koike, K. (2014). Delineation and interpretation of spatial coseismic response of groundwater levels in shallow and deep parts of an alluvial plain to different earthquakes: A case study of the Kumamoto City area, southwest Japan, Journal of Asian Earth Sciences, 83, 35-47.

Pınar, N., Lahn, E. (1952). Earthquake Cataloque of Turkey with Explanations, "TC Bayındırlık BakanlığgıYapı ve İmar İşleri Reisliği” Press, Ankara.

Polat, A., Tatar, O., Gürsoy, H., Karabacak, V., Zabcı, C., Sançar, T. (2012).Paleoseismological findings on the Ortakoy-Suşehri Segment of the 1939 Erzincan Earthquake Surface Rupture, North Anatolian Fault Zone, Geological Bulletin of Turkey, 55, 3, 137-157.

Rockwell, T., Ragona, D., Seitz, G., Langridge, R., Aksoy, M.E., Ucarkus, G., Ferry, M., Meltzner, A.J., Klinger, Y., Meghraoui, M., Satir, D., Barka, A., Akbalik, B. (2009).Palaeoseismology of the North Anatolian Fault near the Marmara Sea: Implications for fault segmentation and seismic hazard, in Palaeoseismology: Historical and Prehistorical Records of Earthquake Ground Effects for Seismic Hazard Assessment, 
edited by K. Reicherter, A. M. Michetti, and P. G. Silva, Geol. Soc. Spec. Publ., 316(1), 31-54, doi:10.1144/SP316.3

Roff, G., Clark, T.R., Reymond, C.E., Zhao, J.-X., Feng, Y.-X., McCook, L.J., Done, T.J., Pandolfi, J.M., Pandolfi, M. (2013). Palaeoecological evidence of a historical collapse of corals at Pelorus Island, inshore Great Barrier Reef, following European settlement, Proc. R. Soc. Lond. B Biol. Sci., 280.

Seed, H.B., Idriss, I.M. (1971).Simplified procedure for evaluating soil liquefaction potential, $J$. Soil Mech. Found. Div., ASCE 97, 1249-1273.

Şengör, A., Tuysuz, O., Imren, C., Sakinc, M., Eyidogan, H., Gorur, N., Le Pichon, X., Rangin, C. (2005). The North Anatolian Fault: A New Look, Annu. Rev. Earth. Pl. Sc., 33, 37-112; doi:10.1146/annurev.earth.32.101802.120415.

Shebalin, N.V., Tatevossian, R.E. (1997). Catalogue of large historical earthquakes of the Caucasus. In: Giardini D. and Balassanian S. (eds), Historical and Prehistorical Earthquakes in the Caucasus, NATO ASI Series 2: Environment - vol. 28, Kluwer Academic Publishers, 201-232.

Shi, Z., Zhang, S., Yan, R., Wang, G. (2018). Fault zone permeability decrease following large earthquakes in a hydrothermal system, Geophysical Research Letters, 45, 1387-1394, doi: 10.1002/2017GL075821.

Sibson, R.H. (1987). Earthquake rupturing as a mineralizing agent in hydrothermal systems, Geology, 15, 701-704.

Stein, R.S., Barka, A.A., Dieterich, J.H. (1997). Progressive failure on the North Anatolian fault since 1939 by earthquake stress triggering, Geophys. J. Int., 128, 594-604.

Uysal, I.T., Feng, Y., Zhao, J., Isık, V., Nuriel, P., Golding, S.D. (2009). Hydrothermal $\mathrm{CO}_{2}$ degassing in seismically active zones during the late Quaternary, Chem. Geol., 265, 442454.

Uysal, I.T., Feng, Y., Zhao, J-X., Altunel, E., Weatherley, D., Karabacak, V., Cengiz, O., Golding, S.D, Lawrance, M.G., Collerson, K.D. (2007). U-series dating and geochemical tracing of late Quaternary travertine in co-seismic fissures, Earth and Planetary Science Letters, 257 (2007) 450-462.

Uysal, I.T., Feng, Y.-X., Zhao, J.-X., Bolhar, R., Isik, V., Baublys, K.A., Yago, A., Golding, S.D. (2011). Seismic cycles recorded in late Quaternary calcite veins: geochronological, geochemical and microstructural evidence, Earth and Planetary Science Letters, 303, 84 96.

Uysal, I.T., Ünal-İmer, E., Shulmeister, J., Zhao, J-X., Karabacak, V., Feng, Y.-X., Bolhar, R. (2019). Linking $\mathrm{CO}_{2}$ degassing in active fault zones to long-term changes in water balance 
and surface water circulation, an example from SW Turkey, Quaternary Science Reviews, 214, 164-177.

Wang, C.-Y., Wang, C.H., Kuo, C.-H. (2004). Temporal change in groundwater level following the $1999(\mathrm{Mw}=7.5)$ Chi-Chi earthquake, Taiwan, Geofluids, 4, 210-220.

Wells, S., Coppersmith, K. (1994). New Emprical Relationships among magnitüd, rupture length, rupture area and surface displacement, Bull. Seism.Soc. Am. 84, 974-1002.

Williams, R.T., Goodwina, L.B., Sharpb, W.D., Mozley, P.S. (2017). Reading a 400,000-year record of earthquake frequency for an intraplate fault, Proceedings of the National Academy of Sciences, 114, 4983-4898.

Yeats, R.S. (2007). Paleoseismology: Why can't earthquakes keep on schedule?, Geology, 35(9), 863, doi:10.1130/focus092007.1.

Zabcı, C., Akyüz, H.S., Karabacak, V., Sancar, T., Altunel, E., Gürsoy, H., Tatar, O. (2011).Paleoearthquakes on the Kelkit Valley segment of the North Anatolian Fault, Turkey: implications for the surface rupture of the historical 17 August 1668 Anatolian Earthquake, Turkish Journal of Earth Sciences, 20, 411-427.

Zhao, J.-X., Hu, K., Collerson, K.D., Xu, H. (2001).Thermal ionization mass spectrometry Useries dating of a hominid site near Nanjing, China, Geology, 29, 27-30.

This article is protected by copyright. All rights reserved. 

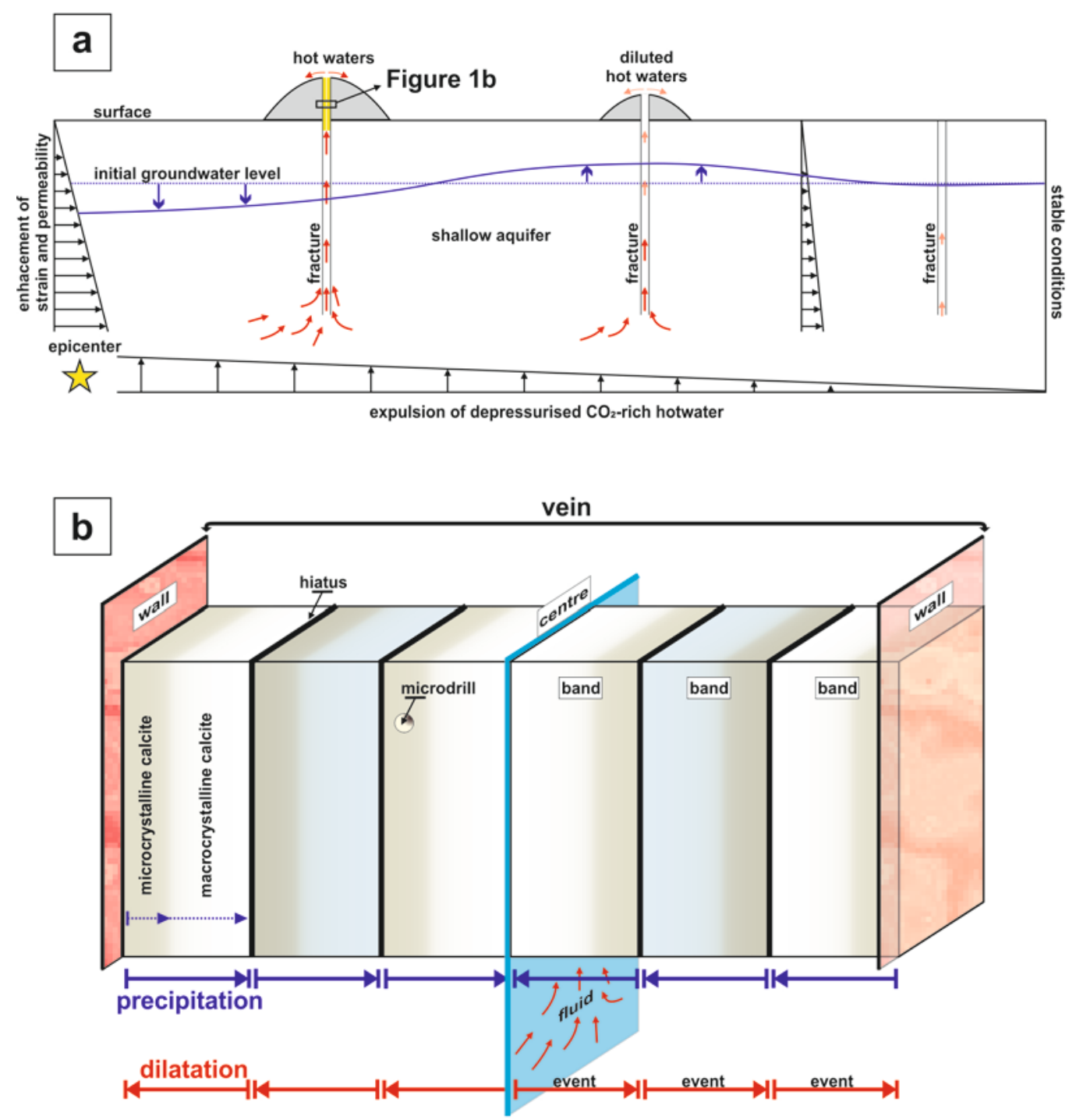

Figure 1. a. Model on co-seismic behaviour of groundwater and fluid circulation in fractures.b. The simplified internal structure of a carbonate vein with alternated bands. 

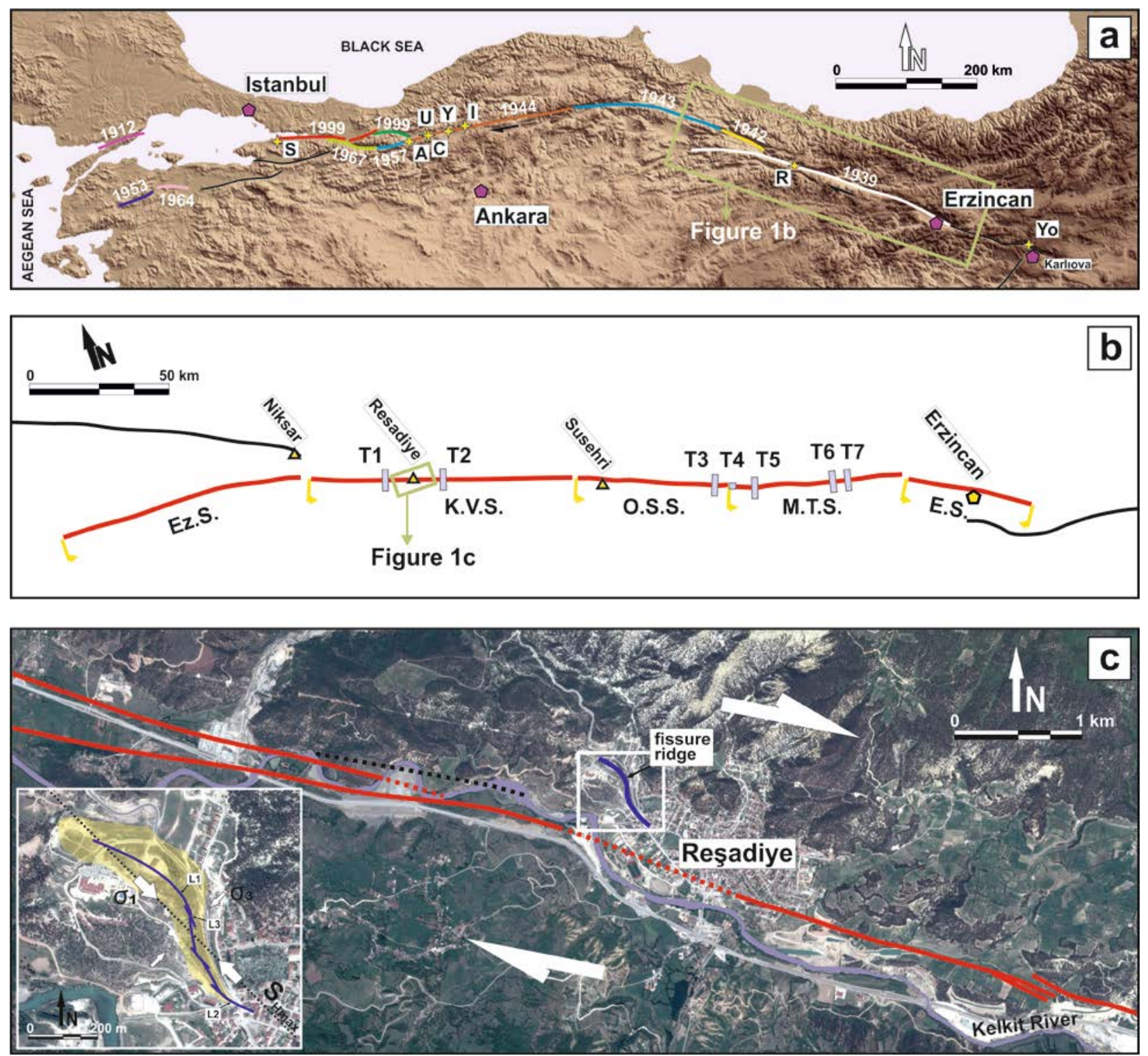

Figure 2. a. Surface rupturing earthquakes during the last century in North Anatolia (generated using the GTOPO30 digital data). Yellow stars show some fissure-ridge travertine sites along the NAFZ; S: Sogucak, A: Cepni, U: Uctepeler, C: Cigdem, Y: Yenicag, I: Imanlar, R: Reşadiye, Yo: Yoncalık. b. General extension of 1939 Erzincan earthquake-rupture. Note that, blue rectangles indicate previous paleoseismic trenching sites on segments and yellow arrows indicate the bounds of geometric segments; Ez.S.:Ezinepazarı, K.V.S.: Kelkit Valley, O.S.S.: OrtaköySuşehri, M.T.S.: Mihar-Tumekar, E.S.: Erzincan Segments. c. Location of the Reşadiye fissureridge travertine along the NAFZ. Red line indicates 1939 Earthquake rupture (redrawn from Zabc1 et al. 2011, Emre et al. 2012 and Gürsoy et al. 2013 on the basis of authors' field 
observations). Note that inset photo shows detailed geometry of the carbonate vein and sampling sites. The dashed line shows the maximum horizontal compressional stress axis $\left(\mathrm{S}_{\mathrm{Hmax}}\right)$ (from the World Stress Map Project database WSM, Heidbach et al., 2016) (the base maps were taken from Google Earth software). 


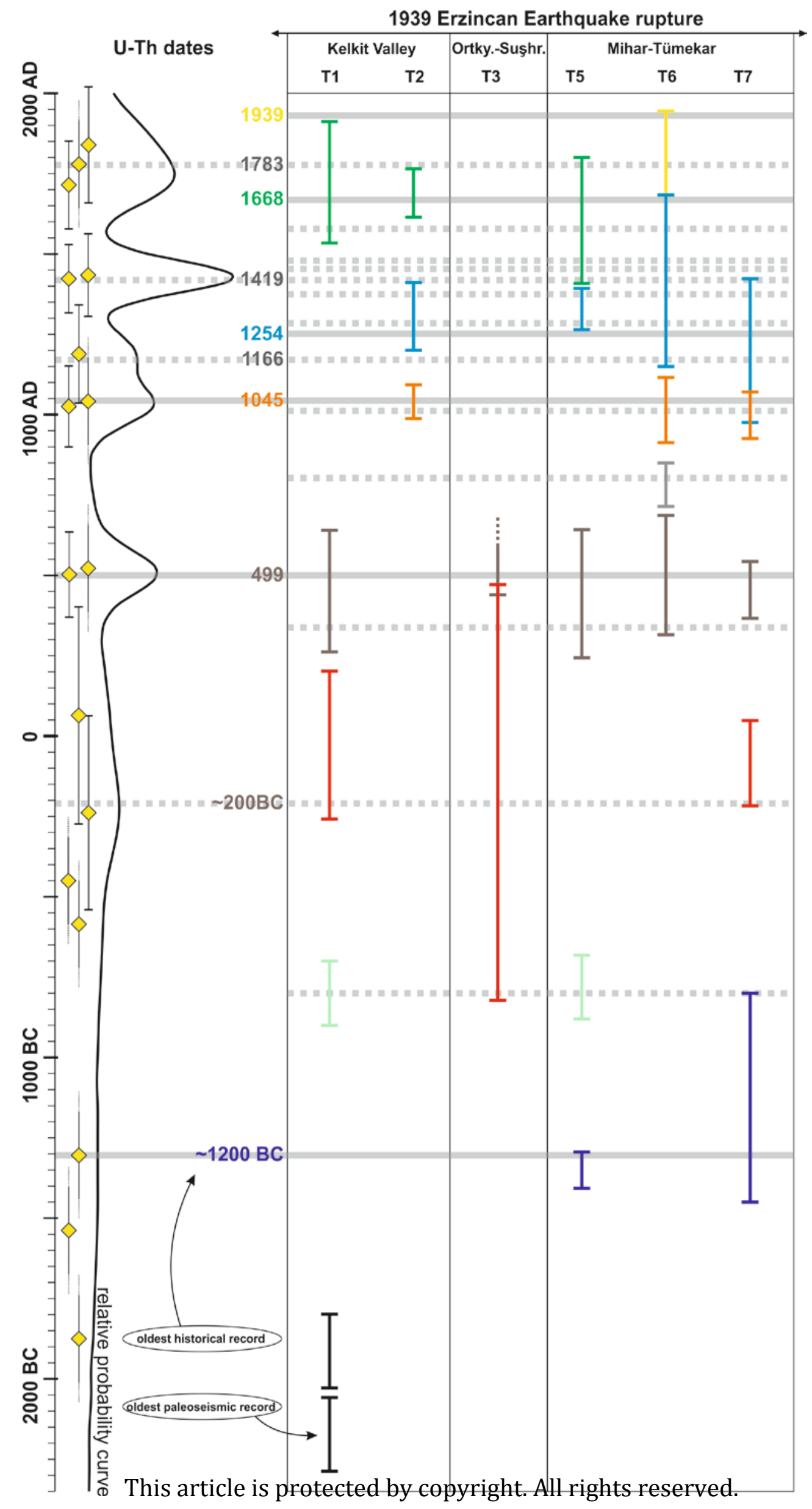


Figure 3. Dated paleoseismic events on previous trench studies along the 1939 rupture segment and comparison with our U-Th dating results. Vertical bars on each trenching study shows analytically dated event boundaries (coloured the same with related historical earthquake). Horizontaldashed lines show the calendar date of events suggested by the historical earthquake records or paleoseismic trenching results (solid line for both records). Note that horizontal lines extended to the related peak on relative probability curve project our results. 

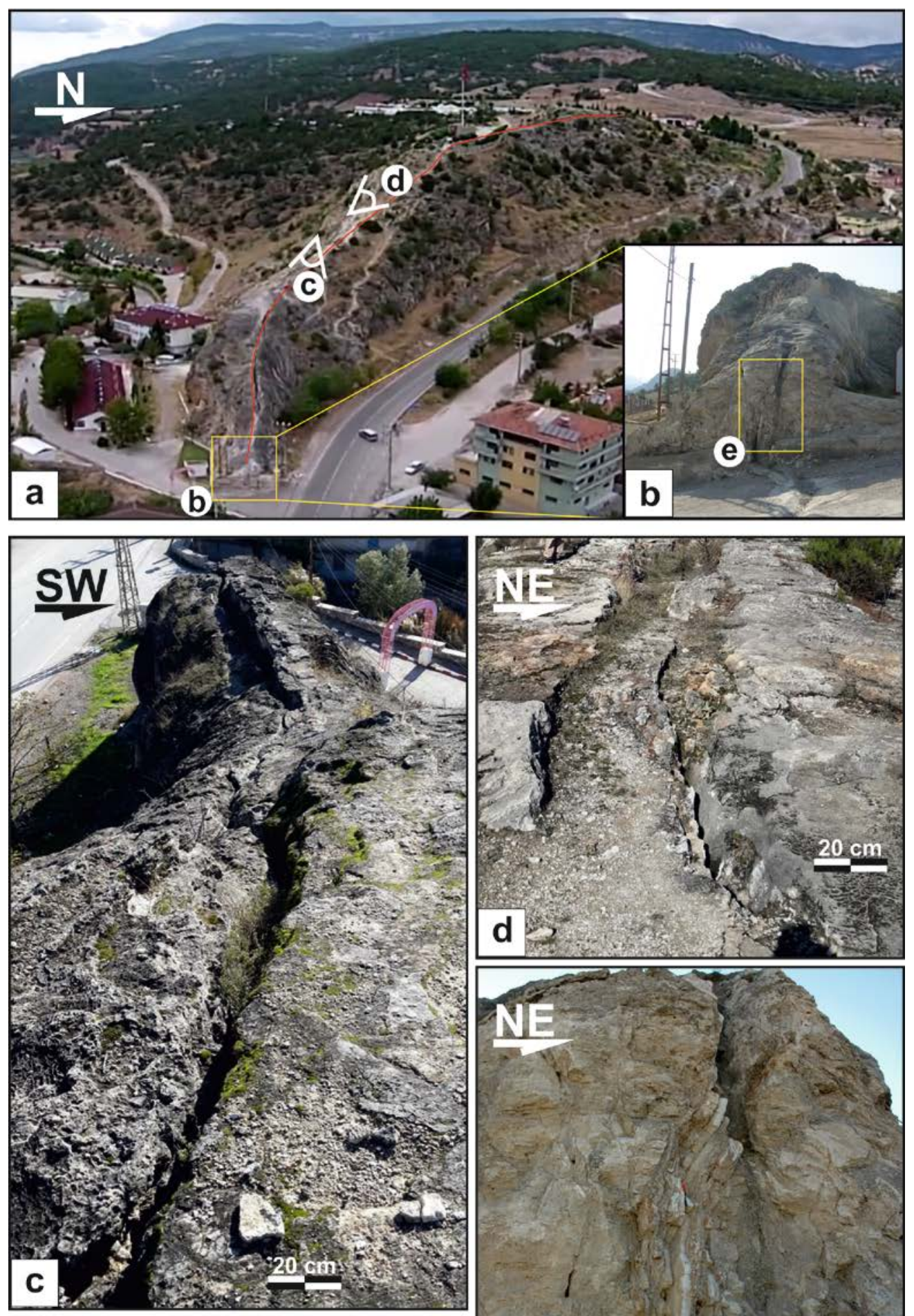

e

This article is protected by copyright. All rights reserved. 
Figure 4. Field views of the Reşadiye fissure-ridge travertine $(\mathrm{a}-\mathrm{c})$ and sampled carbonate veins; location 2 (d) and location 3 (e). 

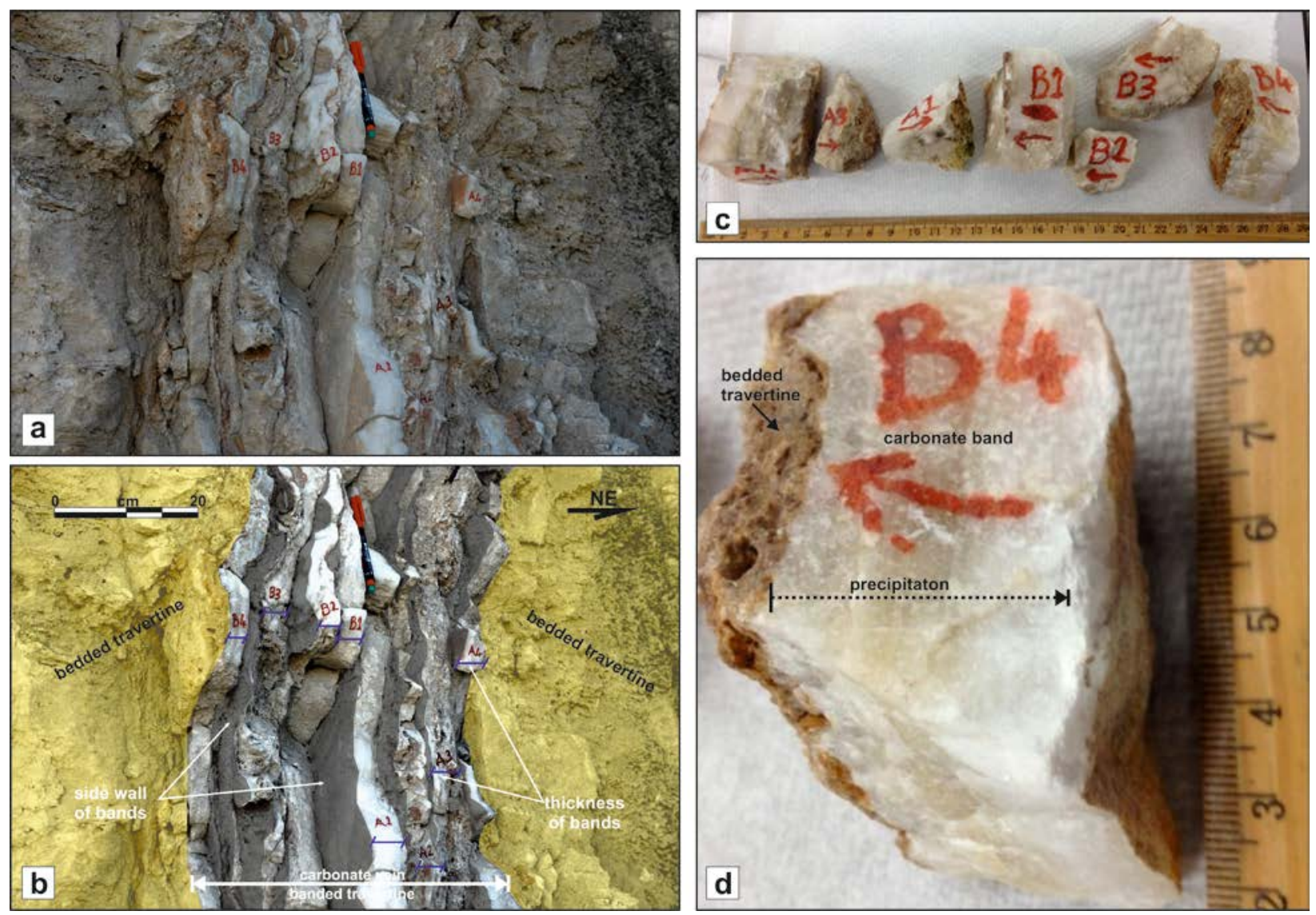

Figure 5. a. Field view of the sampling location L2. b. Representative photo of the vein with sample labels (Samples 9-15). c. Hand-samples for laboratory. d. Close view of the B4 band (Dashed black arrow shows the direction of precipitation. Note that arrow on the sample show the candidate dating point determined in the field). 
Table 1. General features of sampling bands and summary of the age data. Note that the samples with star represent analyses with an error rate exceeding $38 \%$.

\begin{tabular}{|c|c|c|c|c|c|c|c|c|c|c|c|}
\hline \multirow[b]{2}{*}{ } & \multirow[b]{2}{*}{ 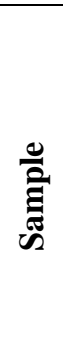 } & \multirow[b]{2}{*}{$\frac{\sqrt{0}}{\stackrel{0}{0}}$} & \multirow[b]{2}{*}{ 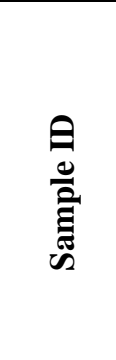 } & \multirow{2}{*}{ 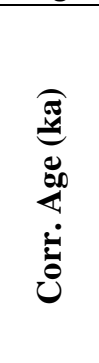 } & \multirow[b]{2}{*}{$\underset{\sim}{\stackrel{+}{+1}}$} & \multirow{2}{*}{ 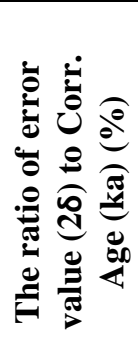 } & \multirow{2}{*}{ 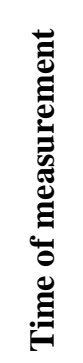 } & \multicolumn{2}{|c|}{$\begin{array}{c}\text { Conv. years } \\
\text { BP (1950) }\end{array}$} & \multicolumn{2}{|c|}{$\begin{array}{c}\text { Calendar } \\
\text { years } \\
\text { (AD/BC) } \\
\end{array}$} \\
\hline & & & & & & & & Age & $\begin{array}{c} \pm 2 \delta \\
\text { (years) }\end{array}$ & Age & $\pm 2 \delta$ \\
\hline \multirow{8}{*}{$\mathbf{L 1}$} & 1 & N45-50W/90 & RS-1a & 1.060 & 0.124 & 12 & 2016 & 994 & 124 & 1024 & 124 \\
\hline & 2 & N45-50W/90 & RS-1b & 0.661 & 0.092 & 14 & 2016 & 595 & 92 & 1423 & 92 \\
\hline & 3 & $\mathrm{~N} 45-50 \mathrm{~W} / 90$ & $\mathrm{RS}-1 \mathrm{c}^{*}$ & 0.245 & 0.182 & 74 & 2016 & 179 & 182 & 1839 & 182 \\
\hline & 4 & N45-50W & RS-2 & 0.373 & 0.143 & 38 & 2016 & 307 & 143 & 1711 & 143 \\
\hline & 5 & N45-50W/90 & RS-3 & 0.650 & 0.126 & 19 & 2016 & 584 & 126 & 1434 & 126 \\
\hline & 6 & N55-60W/80SW & RS-4 & 6.957 & 0.657 & 9 & 2016 & 6891 & 657 & -4873 & 657 \\
\hline & 7 & N55-60W/70NE & RS-6 & 1.579 & 0.136 & 9 & 2016 & 1513 & 136 & 505 & 136 \\
\hline & 8 & N55-60W & RS-7 & 3.961 & 1.507 & 38 & 2016 & 3895 & 1507 & -1877 & 1507 \\
\hline \multirow{7}{*}{$\mathbf{L} 2$} & 9 & N60-65W/80SW & A1 (B) & 3.386 & 0.809 & 24 & 2012 & 3324 & 809 & -1306 & 809 \\
\hline & 10 & N60-65W/80SW & $\begin{array}{c}\text { A4 } \\
(\mathrm{T})^{*}\end{array}$ & 6.744 & 5.890 & 87 & 2012 & 6682 & 5890 & -4664 & 5890 \\
\hline & 11 & N60-65W/80SW & $\begin{array}{c}\text { B1 } \\
(\mathrm{B})^{*}\end{array}$ & 4.918 & 5.353 & 109 & 2012 & 4856 & 5353 & -2838 & 5353 \\
\hline & 12 & N60-65W/80SW & $\begin{array}{l}\text { B4 } \\
(\mathrm{T})^{*}\end{array}$ & 3.615 & 2.340 & 65 & 2012 & 3553 & 2340 & -1535 & 2340 \\
\hline & 13 & N60-65W/80SW & A $3 *$ & 4.656 & 2.993 & 64 & 2012 & 4594 & 2993 & -2576 & 2993 \\
\hline & 14 & N60-65W/80SW & B3* & 2.530 & 2.329 & 92 & 2012 & 2468 & 2329 & -450 & 2329 \\
\hline & 15 & N60-65W/80SW & B2 & 5.525 & 1.527 & 28 & 2012 & 5463 & 1527 & -3445 & 1527 \\
\hline \multirow{7}{*}{$\mathbf{L 3}$} & 16 & N50-55W/90 & $\mathrm{R} 8 \mathrm{a}$ & 2.657 & 0.480 & 18 & 2005 & 2602 & 480 & -584 & 480 \\
\hline & 17 & N50-55W/90 & $\mathrm{R} 8 \mathrm{~b}$ & 1.545 & 0.485 & 31 & 2005 & 1490 & 485 & 528 & 485 \\
\hline & 18 & N50-55W/90 & $\mathrm{R} 8 \mathrm{c}$ & 2.006 & 0.357 & 18 & 2005 & 1951 & 357 & 67 & 357 \\
\hline & 19 & N50-55W/90 & $\mathrm{R} 8 \mathrm{~d}$ & 2.314 & 0.296 & 13 & 2005 & 2259 & 296 & -241 & 296 \\
\hline & 20 & N50-55W/90 & R8e* & 0.290 & 0.486 & 168 & 2005 & 235 & 486 & 1783 & 486 \\
\hline & 21 & N50-55W/90 & R8f & 0.889 & 0.152 & 17 & 2005 & 834 & 152 & 1184 & 152 \\
\hline & 22 & N50-55W/90 & R8g* & 1.041 & 1.235 & 119 & 2005 & 986 & 1235 & 1032 & 1235 \\
\hline
\end{tabular}


Table 2. Summary of the correlations between carbonate ages and earthquake records.

\begin{tabular}{|c|c|c|c|c|c|c|c|}
\hline & \multirow{3}{*}{$\begin{array}{l}\text { Sample } \\
\text { ID }\end{array}$} & \multicolumn{4}{|c|}{$\begin{array}{c}\text { Calculated carbonate ages } \\
(\mathrm{AD} / \mathrm{BC})\end{array}$} & \multirow{2}{*}{\multicolumn{2}{|c|}{$\begin{array}{c}\text { Correlated earthquake records } \\
\text { (Date) }(\mathrm{AD} / \mathrm{BC})\end{array}$}} \\
\hline & & \multicolumn{2}{|c|}{$\begin{array}{l}\text { U-Th age } \\
\text { results }\end{array}$} & \multicolumn{2}{|c|}{$\begin{array}{c}\text { Relative } \\
\text { probability peaks }\end{array}$} & & \\
\hline & & Age & $\pm 2 \delta$ & Age & $\pm 2 \delta$ & $\begin{array}{l}\text { Historical } \\
\text { catalogues }\end{array}$ & $\begin{array}{c}\text { Paleoseismological } \\
\text { studies }\end{array}$ \\
\hline 1 & RS-1c & $1839 \mathrm{AD}$ & 182 & \multirow{3}{*}{$1760 \mathrm{AD}$} & \multirow{3}{*}{150} & \multirow{3}{*}{$1783 \mathrm{AD}$} & \multirow{3}{*}{ n.a. } \\
\hline 2 & R8e & $1783 \mathrm{AD}$ & 486 & & & & \\
\hline 3 & RS-2 & $1711 \mathrm{AD}$ & 143 & & & & \\
\hline 4 & RS-3 & $1434 \mathrm{AD}$ & 126 & \multirow{2}{*}{$1430 \mathrm{AD}$} & \multirow{2}{*}{52} & \multirow{2}{*}{$1419 \mathrm{AD}$} & \multirow{2}{*}{$\begin{array}{l}\text { 1400-1600 AD (varve } \\
\text { record) }\end{array}$} \\
\hline 5 & RS-1b & $1423 \mathrm{AD}$ & 92 & & & & \\
\hline 6 & R8f & $1184 \mathrm{AD}$ & 152 & $1170 \mathrm{AD}$ & 150 & $1166 \mathrm{AD}$ & n.a. \\
\hline 7 & $\mathrm{R} 8 \mathrm{~g}$ & $1032 \mathrm{AD}$ & 1235 & \multirow{2}{*}{$1040 \mathrm{AD}$} & \multirow{2}{*}{107} & \multirow{2}{*}{1045 AD } & \multirow{2}{*}{$1045 \mathrm{AD}$} \\
\hline 8 & RS-1a & $1024 \mathrm{AD}$ & 124 & & & & \\
\hline 9 & $\mathrm{R} 8 \mathrm{~b}$ & $528 \mathrm{AD}$ & 485 & \multirow{2}{*}{$500 \mathrm{AD}$} & \multirow{2}{*}{140} & \multirow{2}{*}{$499 \mathrm{AD}$} & \multirow{2}{*}{$499 \mathrm{AD}$} \\
\hline 10 & RS-6 & $505 \mathrm{AD}$ & 136 & & & & \\
\hline 11 & R8c & $67 \mathrm{AD}$ & 357 & \multirow{4}{*}{$200 \mathrm{BC}$} & \multirow{4}{*}{234} & \multirow{4}{*}{ n.a. } & \multirow{4}{*}{$\sim 200 \mathrm{BC}$} \\
\hline 12 & R8d & $241 \mathrm{BC}$ & 296 & & & & \\
\hline 13 & B3 & $450 \mathrm{BC}$ & 2329 & & & & \\
\hline 14 & R8a & $584 \mathrm{BC}$ & 480 & & & & \\
\hline 15 & A1 (B) & $1306 \mathrm{BC}$ & 809 & \multirow{2}{*}{$1390 \mathrm{BC}$} & \multirow{2}{*}{550} & \multirow{2}{*}{$\sim 1200 \mathrm{BC}$} & \multirow{2}{*}{$\sim 1200 \mathrm{BC}$} \\
\hline 16 & $\mathrm{~B} 4(\mathrm{~T})$ & $1535 \mathrm{BC}$ & 2340 & & & & \\
\hline 17 & RS-7 & $1877 \mathrm{BC}$ & 1507 & ???? & & n.a. & $1804-2020 \mathrm{BC}$ \\
\hline 18 & A3 & $2576 \mathrm{BC}$ & 2993 & $? ? ? ?$ & & n.a. & $2066-2280 \mathrm{BC}$ \\
\hline 19 & B1 (B) & $2838 \mathrm{BC}$ & 5353 & $? ? ? ?$ & & n.a. & n.a. \\
\hline 20 & B2 & $3445 \mathrm{BC}$ & 1527 & ???? & & n.a. & n.a. \\
\hline 21 & A4 (T) & $4664 \mathrm{BC}$ & 5890 & \multirow{2}{*}{$4770 \mathrm{BC}$} & \multirow{2}{*}{693} & \multirow{2}{*}{ n.a. } & \multirow{2}{*}{ n.a. } \\
\hline 22 & RS-4 & $4873 \mathrm{BC}$ & 657 & & & & \\
\hline
\end{tabular}



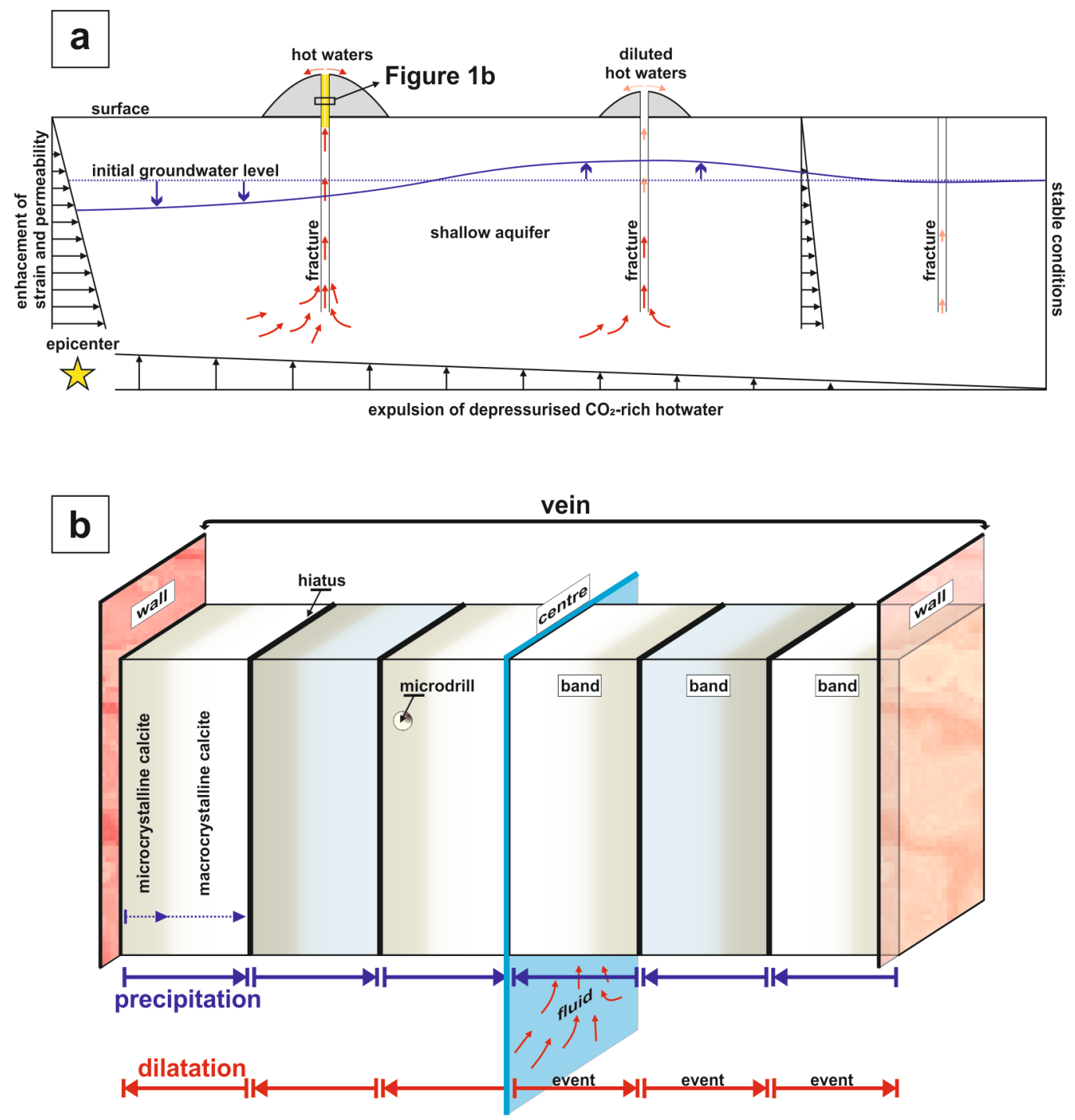

2018TC005450-f01-z-.jpg

This article is protected by copyright. All rights reserved. 

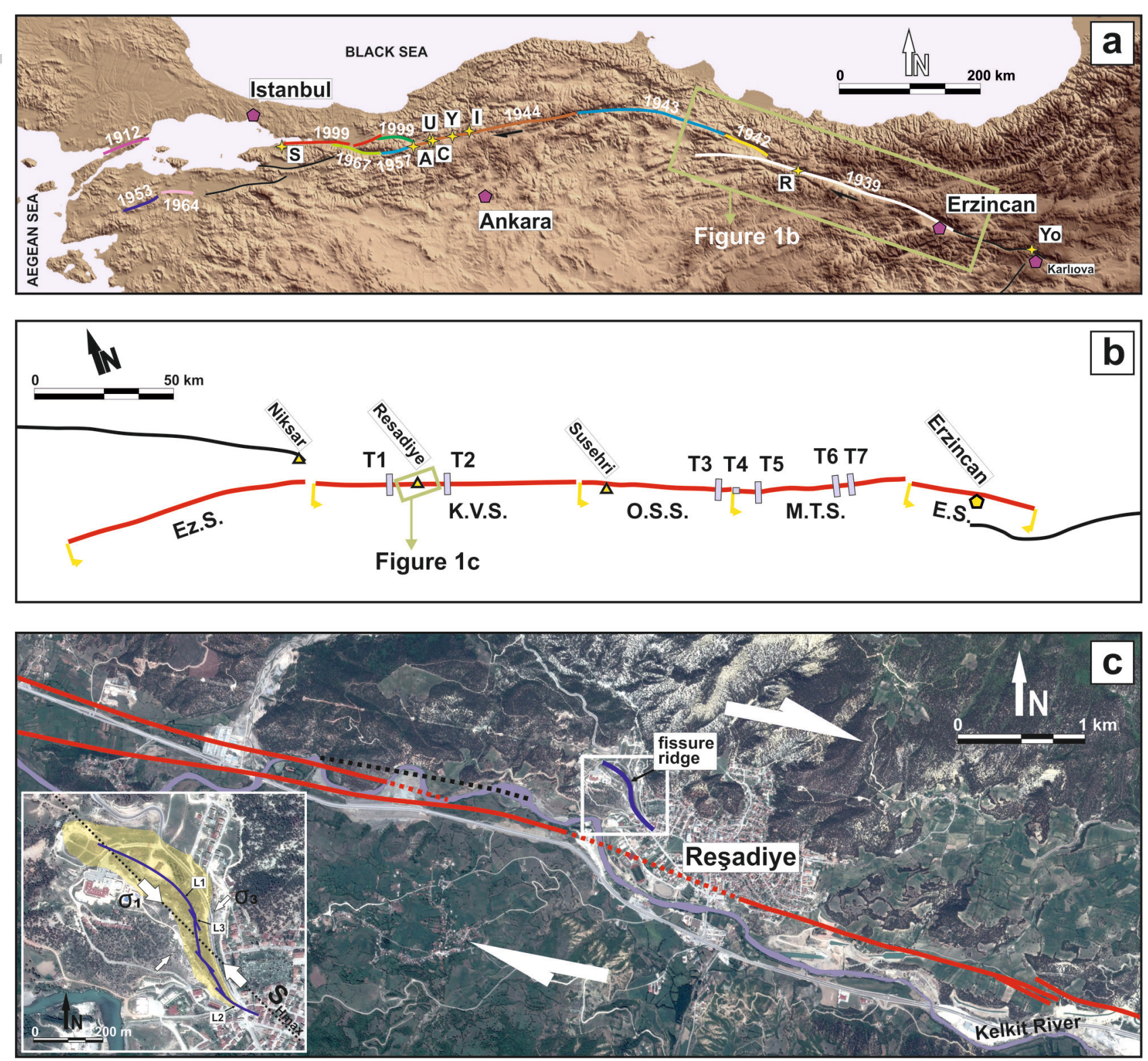

2018TC005450-f02-z-.jpg

This article is protected by copyright. All rights reserved. 
1939 Erzincan Earthquake rupture

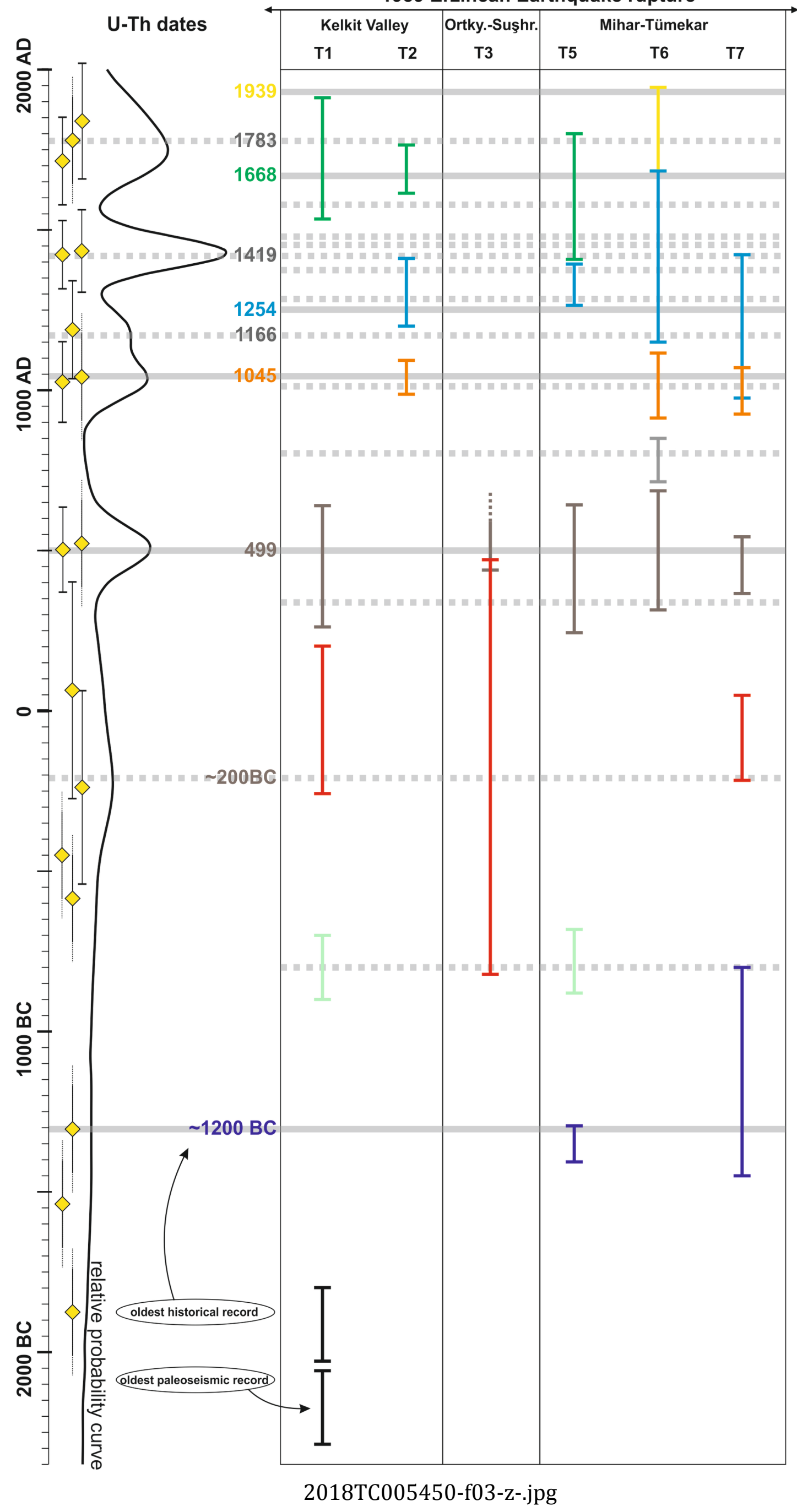

This article is protected by copyright. All rights reserved. 

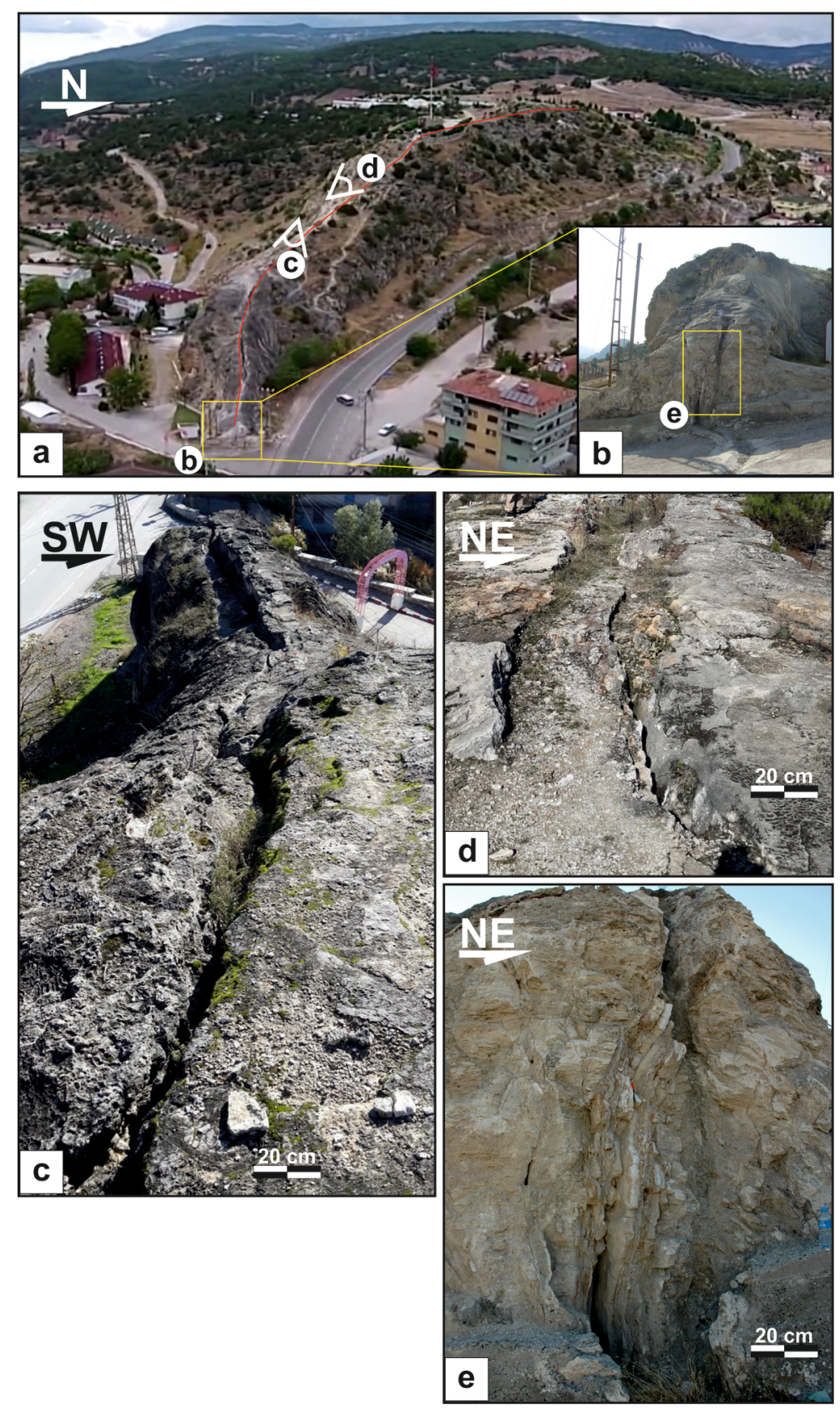

2018TC005450-f04-Z-.jpg

This article is protected by copyright. All rights reserved. 

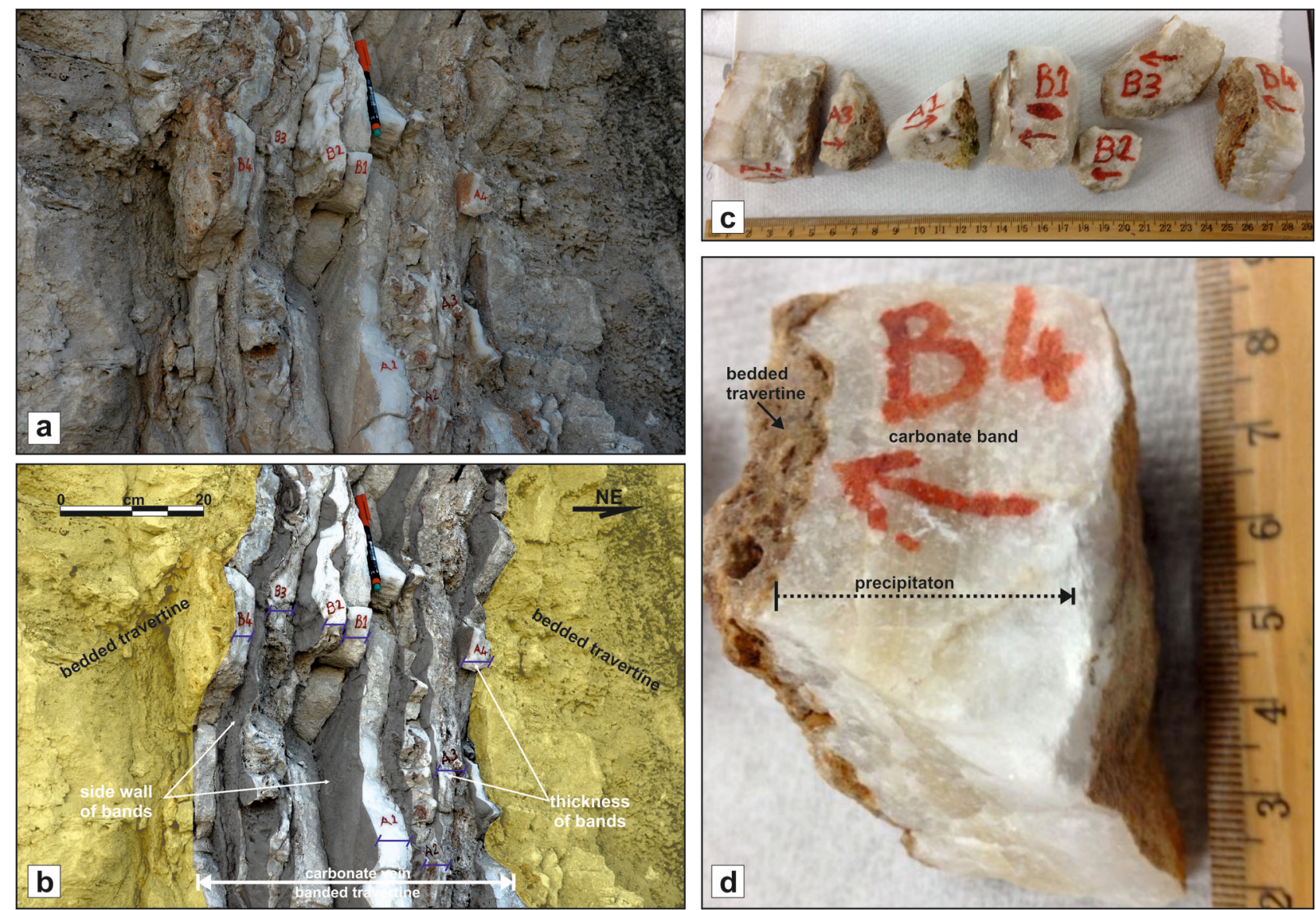

2018TC005450-f05-z-.jpg 